\title{
PARTICIPAÇÃO DA MASTIGAÇÃO E DA GENGIVA CERATINIZADA NA FISIOLOGIA DO SULCO GENGIVAL
}

Maria Luiza Esteves Pacheco Lagos

Dissertação apresentada à Faculdade de Odontologia de Bauru, da Universidade de São Paulo, como parte dos requisitos para obtenção do título de Mestre em Odontologia - Área de Periodontia.

BAURU 


\section{PARTICIPAÇÃO DA MASTIGAÇÃO E DA GENGIVA CERATINIZADA NA FISIOLOGIA DO SULCO GENGIVAL}

Maria Luiza Esteves Pacheco Lagos

Dissertação apresentada à Faculdade de Odontologia de Bauru, da Universidade de São Paulo, como parte dos requisitos para obtenção do título de Mestre em Odontologia - Área de Periodontia.

Orientador: Prof. Dr. Euloir Passanezi

BAURU 


\begin{tabular}{|c|}
\hline $\mathrm{L} 137 \mathrm{p}$ Lagos, Maria Luiza Esteves Pacheco \\
fisiologia do sulco gengival / Maria Luiza Esteves Pacheco \\
Bauru, 2003. \\
100p.: il.; $31 \mathrm{~cm}$. \\
Dissertação (Mestrado) - Faculdade de Odontologia de \\
Bauru. Universidade de São Paulo. \\
Orientador: Prof. Dr. Euloir Passanezi
\end{tabular}

Autorizo, exclusivamente para fins acadêmicos e científicos, a reprodução total ou parcial desta dissertação/tese, por processos fotocopiadores e outros meios eletrônicos.

Assinatura:

Comitê de Ética da FOB

No. do Protocolo:

Data: 


\section{MARIA LUIZA ESTEVES PACHECO LAGOS}

15 de março de 1966 Nascimento

Regente Feijó-SP

Graduação em Odontologia

1986-1991

Universidade Estadual de Londrina, Londrina-PR

1992-1993

Curso de Especialização em Periodontia

Escola de Aperfeiçoamento Profissional Associação

Odontológica do Norte do Paraná, Londrina-PR

Professora Colaboradora do Departamento de

1994-1995 Odontologia, área de concentração em Periodontia, do Curso de Odontologia da Universidade Estadual de Maringá, Maringá-PR

Professor Auxiliar de Ensino I do Departamento de 1995-1996 Odontologia, área de concentração em Periodontia, do Curso de Odontologia da Universidade Estadual de Maringá, Maringá-PR

ABO-PR - Associação Brasileira de Odontologia Associações Secção Paraná

CRO-PR - Conselho Regional de Odontologia do Paraná - n. 7780 
Quando se viaja em direção a um objetivo é muito importante prestar atenção no caminho.

O caminho é que sempre nos ensina a melhor maneira de chegar, e nos enriquece, enquanto o estamos cruzando.

Paulo Coelho - "O Diário de um Mago" 


\title{
DEDICO ESTE TRABALHO
}

\author{
À DEUS, \\ pela Fonte de Vida, pela Luz que guia meu caminho, pelo \\ Discernimento e Sentido de minha Existência.
}

\section{AOS MEUS PAIS ELIOSÉ E TONA,}

compreensão, amor e apoio incondicional;

pela dedicação, por me darem condições necessárias para chegar até aqui, o Estudo.

Esta etapa pertence a vocês.

\section{AO MEU MARIDO CARLOS,}

companheiro, amigo, minha química... Desde o início meu maior encorajador e incentivador, suportando e entendendo minha ausência, e acima de tudo acreditando em nós.

\section{AOS MEUS FILHOS:}

\section{AMANDA, LEONARDO E FERNANDO,}

luzes radiantes de pureza...

meu sentido de vida, de amor, de alegria. Desculpem-me pela ausência em preciosos momentos de convivência durante a realização deste trabalho. Apesar de ainda não compreenderem a razão de tudo isto, vocês são o principal incentivo às nossas realizações (minha e do papai). 


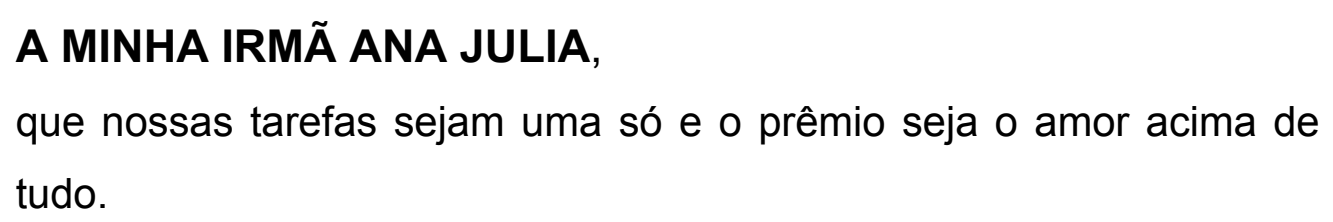

\section{A Vó LUIZA, VÓ JULIA, VÔ PACHECO, MEU IRMÃO PIPOCA E TIA ELZA,}

sei que de onde quer que vocês estejam, torceram por mim e suas luzes me iluminaram.

\section{AOS MEUS FAMILIARES,}

cada um de vocês, a seu modo foram e são fundamentais à minha jornada.

Dedico a vocês este trabalho. 
As pessoas se tornam especiais não apenas por sua maneira de ser ou agir, mas sim, pela profundidade com que tocam nossos sentimentos. 


\section{AGRADECIMENTO ESPECIAL}

\section{AO PROF. DR. EULOIR PASSANEZI,}

a quem devoto minha sincera admiração pelo exemplo profissional e humano, que me acompanhou e auxiliou em todas etapas deste trabalho, tornando os momentos difíceis mais fáceis de serem superados.

Obrigada pela confiança e apoio.

Minha eterna gratidão. 


\section{AGRADECIMENTOS}

Ao Prof. Dr. Sebastião Luiz Aguiar Greghi pelos ensinamentos transmitidos, por ser antes de tudo sincero e colega, pelo incentivo no decorrer deste trabalho.

A Profa. Dra. Adriana Campos Passanezi Stana pelo auxilio na orientação em várias etapas deste trabalho, pelas valiosas informações transmitidas, pelos momentos de convívio e pela amizade.

A Profa. Dra. Maria Fidela Navarro, Prof Dr. Newton de Moraes por fazerem de seus sonhos a grande realização de nossos sonhos.

Aos funcionários do departamento de Periodontia: Marcos, Débora, Neusa e em especial a Ivânia e Edilaine pela amizade, atenção e colaboração tão importantes para conclusão deste trabalho.

Ao Ricardo pela atenção e dedicação proporcionados.

Ao Prof. Dr. José Roberto Lauris pelo auxilio na realização e interpretação dos resultados estatísticos. 
Ao Departamento de Materiais Dentários da FOB_USP pelo empréstimo do paquímetro.

A Profa. Dra. Selma Campos Passanezi por me acolher em sua casa e proporcionar condições para que o Prof. Dr. Euloir e a Prof. Dra. Adriana pudessem me ajudar a concluir este estudo.

Ao Departamento de Bioquímica da UEM-PR, na funcionária Marlene que viabilizou o uso do corante utilizado neste trabalho.

A Biblioteca da FOB_USP, na pessoa da Rita pelo auxílio e orientação na correção das normas técnicas.

\section{A três pessoas muito especiais:}

meu professor de inglês Antonio Carlos pelo incentivo e dedicação;

minha professora de computação Helaine pela paciência e companherismo e a,

minha secretária Camila pela incorporação deste trabalho, fazendo dele meta e assim tornando possível toda etapa clínica experimental necessários à sua conclusão. 
Aos Pacientes... pela colaboração, sem vocês este trabalho não seria viável.

A amiga Marcia não só porque "devo isso a você", mas por tudo que aprendi nestes 12 anos.

Aos companheiros e sócios Marcia e Altair por entenderem e preencherem tantas vezes minha ausência sem deixar que isso atrapalhasse o funcionamento da clínica.

As minhas auxiliares Clô, Li, Cléo e Lê pelo carinho e cuidado prestados aos meus filhos e minha casa na minha ausência. Vocês foram fundamentais.

Aos colegas do curso Lucinara, Nely, Édina, Flavio, Paulo, Carrilho, João, Geraldo e Feiz pela convivência e incentivo sempre.

Aos colegas Cynthia, Cintia, Nadir, Alfredo, Murilo, Aline, pelas viagens, companheirismo tão importante em todas etapas deste trabalho. 
A amiga Maria de Lourdes Mesquita pelo incentivo e auxilio nas traduções.

A amiga Cíntia Murad pelo auxílio com as fotografias.

A todos que de alguma forma me ajudaram e contribuíram para que este trabalho pudesse ser realizado. 


\section{SUMÁRIO}

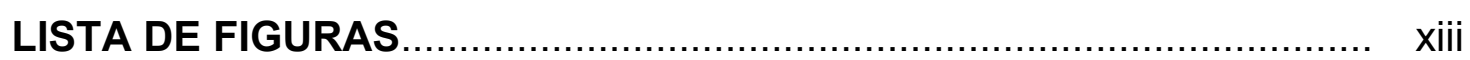

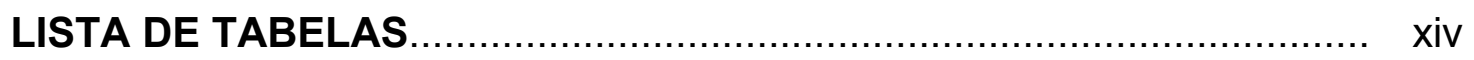

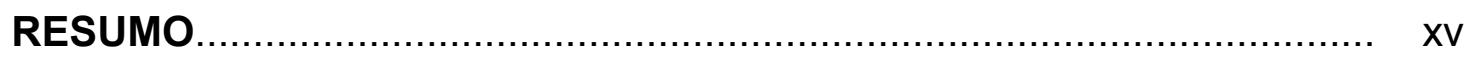

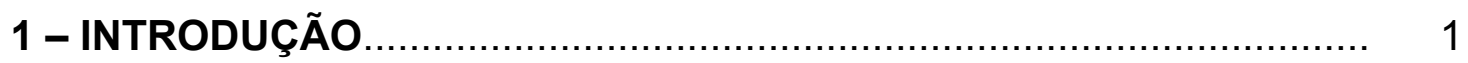

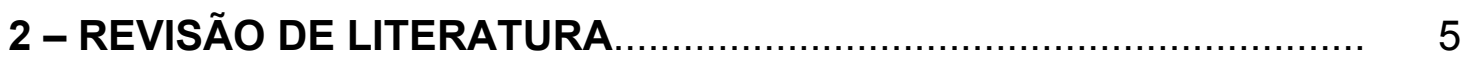

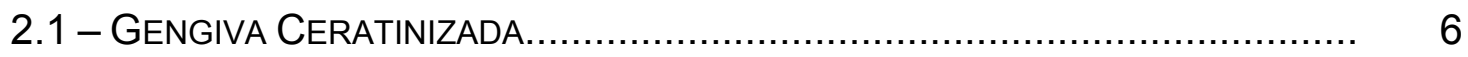

2.2 - FLUIDO GENGIVAL................................................................. 19

2.3 - INFLUÊNCIA DA MASTIGAÇÃO NA PROdUÇÃO do FlUIDO GENGIVAL........... 29

2.4 - PARTICIPAÇÃo do Paciente no Controle de FAtores BACterianos... 32

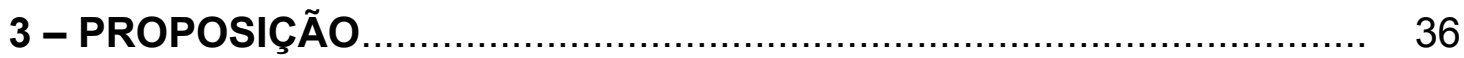

4 - MATERIAL E MÉTODOS....................................................... 38

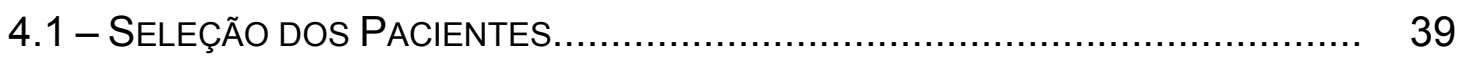

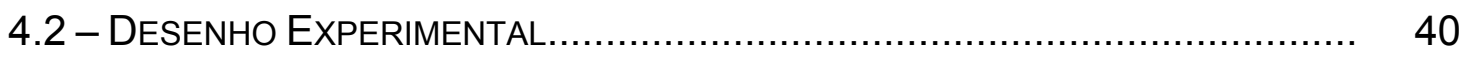

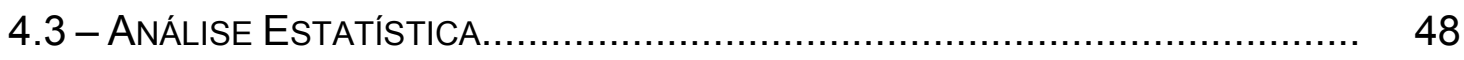

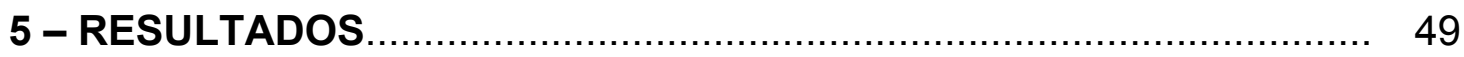

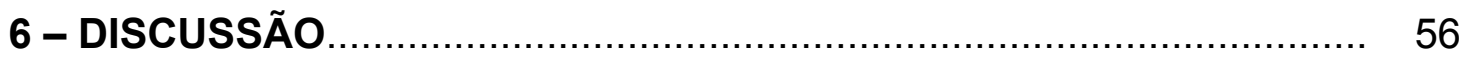

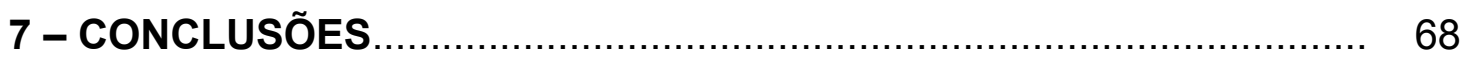

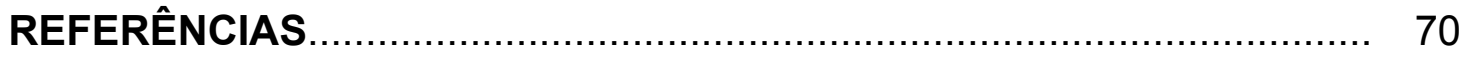

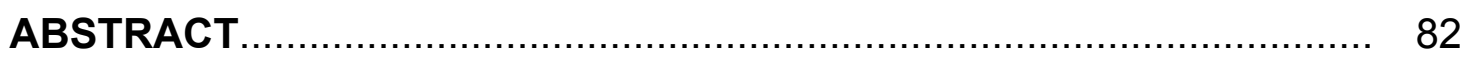




\section{LISTA DE FIGURAS}

FIGURA 1 - Vista clínica da amostra do grupo experimental

FIGURA 2 - Vista e metodologia do paquímetro digital 42

FIGURA 3 - Metodologia de mensuração da profundidade do sulco gengival com sonda periodontal

FIGURA 4 - llustração da metodologia de mensuração do índice de exsudato.46

FIGURA 5 - Ilustração da medição linear longitudinal da área embebida pelo fluido gengival na tira de papel. 


\section{LISTA DE TABELAS}

TABELA 1 - Análise estatística da quantidade de fluido gengival coletada nas regiões que apresentam faixa insuficiente (Grupo $\mathrm{I}<2 \mathrm{~mm}$ ) e faixa adequada (Grupo $A \geq 2 \mathrm{~mm}$ ) de gengiva ceratinizada nas diferentes posições, antes do estímulo mastigatório. 51

TABELA 2 - Análise estatística da quantidade de fluido gengival coletada nas regiões que apresentam faixa insuficiente (Grupo I $<2 \mathrm{~mm}$ ) e faixa adequada (Grupo $A \geq 2 \mathrm{~mm}$ ) de gengiva ceratinizada nas diferentes posições, após o estímulo mastigatório.

TABELA 3 - Análise estatística da quantidade de fluido gengival coletada de áreas com mais de $2 \mathrm{~mm}$ de gengiva ceratinizada (grupo $A$ ) antes e depois da mastigação, nas diferentes posições. 53

TABELA 4 - Análise estatística da quantidade de fluido gengival coletada de áreas com menos de $2 \mathrm{~mm}$ de gengiva ceratinizada (grupo I), antes e depois da mastigação, nas diferentes posições. 54

TABELA 5 - Caracterização clínica dos pacientes por meio dos índices de placa dentobacteriana, sangramento gengival, profundidade de sondagem do sulco gengival, quantidade de gengiva ceratinizada e quantidade de fluido gengival nas áreas com quantidade insuficiente e adequada de gengiva ceratinizada. 55 


\section{RESUMO}

Com o intuito de avaliar o comportamento homeostático do sulco gengival em função da quantidade de gengiva ceratinizada, direcionando-se a análise para a variação da quantidade de fluido gengival produzida pelo estimulo da mastigação de alimentos fibrosos (carne bovina), foram selecionados 16 pacientes com boas condições de saúde geral e áreas de pré-molares e molares homólogas, saudáveis clinicamente, apresentando no lado experimental faixa adequada de gengiva ceratinizada (Grupo $A \geq 2 \mathrm{~mm}$ ) e no lado controle faixa insuficiente de gengiva ceratinizada (Grupo I $<2 \mathrm{~mm}$ ). Os parâmetros clínicos avaliados foram: Índice de placa bacteriana, Índice de sangramento gengival, Profundidade de sondagem, Quantidade de gengiva ceratinizada e Quantidade de fluido gengival. A quantidade de fluido gengival foi obtida antes e após a mastigação de alimento fibroso culinariamente preparado, por 10 minutos, sendo avaliada por meio da impregnação de tiras de filtro de papel absorvente. Conforme proposta de LÖE; HOLM-PEDERSEN, a coleta do fluido gengival foi inicialmente feita por meio da colocação do papel sobre o dente e a mucosa, para embebição do papel na região da mucosa alveolar (P1A) e da margem gengival (P1B), seguindo-se a colocação de outra tira com sua extremidade junto ao orifício de entrada do sulco gengival (P2). Uma terceira tira foi disposta intrasulcularmente (P3), conforme proposto por BRILL e KRASSE. Todas as áreas foram secas previamente com jato de ar e as tiras de papel foram mantidas por 1 minuto em cada posição de cada grupo, depois removidas, deixadas a secar pelo calor, e em seguida embebidas em solução alcoólica de ninidrina a $2 \%$, deixadas secar, e posteriormente as áreas coradas foram medidas com paquímetro digital na sua extensão longitudinal. Os dados coletados foram estatisticamente avaliados por meio do teste "t" de Student pareado. Os dados obtidos neste estudo permitiram concluir que a maior quantidade de gengiva ceratinizada resulta em melhor comportamento 
homeostático do periodonto marginal, pois esta interfere no processo de extravasamento do fluido gengival; a mastigação influencia a quantidade de fluido extravasado marginalmente como fluido gengival; quanto maior a faixa de gengiva ceratinizada, tanto maior parece ser a defesa natural do sulco gengival.

Palavras-chave: gengiva ceratinizada; fluido gengival; mastigação. 
1 INTRODUÇÃO 


\section{INTRODUÇÃO}

Há alguns anos, vários trabalhos têm discutido a importância da faixa de gengiva ceratinizada na homeostasia do periodonto marginal. Alguns autores $^{8,24,38,46,48,53,61,64,72}$ preconizam uma faixa mínima de $2 \mathrm{~mm}$ de gengiva ceratinizada para a manutenção da saúde periodontal, enquanto outros autore $^{13,21,36,76,78,79}$ consideram que a quantidade de gengiva ceratinizada existente seria irrelevante, desde que o paciente apresentasse um bom padrão de higiene bucal, para preservação da saúde.

Dentro deste contexto, grande parte dos autores ${ }^{13,34,40,46,81}$ afirmam que seria possível manter a saúde periodontal sem a necessidade de uma faixa mínima de gengiva ceratinizada, em pacientes mantidos em controle profissional periódico, o que não ocorre freqüentemente, como demonstrado por WILSON JR. et al. ${ }^{84}$ e DEMETRIOU et al. ${ }^{20}$, que observaram, em pacientes em regime de manutenção periodontal, baixo percentual de retorno às consultas agendadas.

Por outro lado, apesar de ser possível a preservação de saúde gengival em áreas de apenas $1 \mathrm{~mm}$ de gengiva ceratinizada, em pacientes com bom nível de controle de placa dentobacteriana, essas regiões estariam mais sujeitas à perda de inserção periodontal ${ }^{13}$. LANG; LÖE ${ }^{38}$ demonstraram sinais clínicos de inflamação, mesmo na ausência de placa dentobacteriana, em áreas com estreita faixa de gengiva ceratinizada $(<2 \mathrm{~mm})$, o que poderia sugerir que o comportamento dos tecidos nessas regiões fosse mais compatível, segundo PASSANEZI et al. ${ }^{61}$, com alterações patológicas do que fisiológicas.

Um dos sinais freqüentemente associados à inflamação gengival é o aumento do fluxo de fluido gengival (PAGE; SHROEDER ${ }^{58}$, WAERHAUG 
apud CIMASONI ${ }^{18}$, LÖE; HOLM-PEDERSEN ${ }^{42}$ ). Assim, a avaliação de pacientes clinicamente saudáveis com quantidade suficiente $(\geq 2 \mathrm{~mm})$ e insuficiente $(<2 \mathrm{~mm})$ de gengiva ceratinizada, segundo critérios estabelecidos por LANG; LÖE ${ }^{38}$, mostraram diferenças na quantidade de fluido gengival extravasado através do sulco, constituindo-se em possível fator de risco para alterações teciduais, justificando a necessidade da presença de quantidade mínima de gengiva ceratinizada.

Um dos fatores que poderia explicar esse fato é que a mucosa alveolar apresenta maior grau de mobilidade e permeabilidade, respectivamente para viabilizar o movimento das estruturas e para permitir 0 reconhecimento de estímulos agressivos antes mesmo que estes tenham invadido o meio interno e atuado nele $e^{44,61,66}$. Essa interação dos mecanismos de defesa é provavelmente explicada por se tratar de um tecido conjuntivo frouxo, ricamente vascularizado. Dessa forma, a existência de pequena faixa de gengiva ceratinizada poria a mucosa alveolar em íntima proximidade com o sulco gengival de modo que ocorreria extravasamento de maior quantidade de fluido gengival na ausência de placa dentobacteriana, justificada por aumento da pressão hidrostática tecidual nas proximidades do epitélio juncional ${ }^{1,2,4,59}$.

A predisposição para formação de placa bacteriana subgengival em áreas onde há movimentação da margem gengival vem justificar a importância da gengiva inserida, pois essa seria capaz de produzir uma imobilização da mesma ${ }^{60}$. Estando a gengiva inserida relacionada à quantidade de gengiva ceratinizada, e estando esta em relação com a junção mucogengival, essas áreas (inserida e ceratinizada) devem ser capazes de neutralizar a tensão transmitida pela mucosa alveolar, sob ação funcional da musculatura, de modo a não produzir movimentação da margem gengival.

Assim, é de se esperar que fatores que possam interferir na homeostasia do periodonto marginal, e que sejam capazes de interferir com o fluxo sangüíneo para a margem gengival, provavelmente possam interferir 
no índice de fluxo do fluido gengival. Um desses fatores, possivelmente, seria a mobilidade da margem gengival, devido à mobilidade do dente ou da musculatura, conforme comentado por BRILL ${ }^{14}$, que demonstrou aumento de fluido gengival estimulado pela mastigação de parafina em áreas com margens gengivais saudáveis.

Parece portanto importante que, apesar de ser possível se manter a saúde periodontal mesmo em regiões com mínima ou até nenhuma faixa de gengiva ceratinizada, a previsibilidade do risco de perda adicional de inserção nestas regiões deve ser considerada. 
2 REVISÃO DE LITERATURA 


\section{REVISÃO DE LITERATURA}

Considerando a participação de diferentes fatores no mecanismo homeostático do periodonto marginal, a revisão da literatura será feita por tópicos que procuram elucidar os envolvimentos próprios desta pesquisa.

\subsection{Gengiva Ceratinizada}

A presença do tônus da margem gengival contra a superfície do dente é um dos importantes mecanismos de defesa, por prover uma barreira mecânica contra partículas de alimentos e bactérias que possam vir adentrar a área sulcular, segundo explanação de BEARDMORE ${ }^{9}$, em 1961. Porém, a presença de um fluxo pequeno mas contínuo de fluido seria responsável pela remoção destes, caso adentrassem a área. Contudo, a função do fluido gengival sem a tonacidade da margem gengival ficaria muito prejudicada. Importante se faz, então, atentar para os fatores que possam alterar o grau do tônus da margem gengival, tais como aumento na profundidade de sondagem e degeneração dos tecidos com formação de bolsa periodontal, que reduziriam a função mecânica da gengiva de cobertura. Apesar de a profundidade de bolsa e a inflamação gengival não terem sido correlacionadas, foi encontrado que o tônus estava inversamente relacionado ao grau de inflamação, o que confirma achados histológicos que sugeriram quebra séria e precoce no mecanismo de defesa local.

Em 1963, BOWERS ${ }^{13}$ demonstrou clinicamente a importância da largura da gengiva inserida na saúde periodontal, sugerindo que gengiva saudável foi encontrada em regiões de $1 \mathrm{~mm}$ de gengiva inserida, e que o 
tecido era normalmente inflamado em áreas onde não havia gengiva inserida. Além disso, correlacionou a variação existente na quantidade de gengiva inserida de pessoa para pessoa e de uma área para outra na mesma pessoa, sendo esta definida por diferentes fatores anatômicos e biológicos relacionados com o nível da margem gengival, porém sem alteração no nível da junção mucogengival. O estudo mostrou que pacientes com margens gengivais clinicamente saudáveis poderiam apresentar faixas de gengiva ceratinizada muito estreitas $(<1 \mathrm{~mm})$, porém com maior risco de apresentar inflamação ao menor descuido na higienização.

A relação entre a largura de gengiva ceratinizada e a saúde gengival foi estudada por LANG; LÖE ${ }^{38}$, em 1972, quando analisaram 32 estudantes de Odontologia na faixa etária de 19 a 29 anos, sem bolsas periodontais e com higiene oral supervisionada, durante 6 semanas. O estudo procurou determinar a largura mínima de gengiva ceratinizada para a manutenção da saúde gengival. Para tanto, analisaram o índice de exsudato sulcular em áreas que apresentavam, no sulco experimental, no mínimo $2 \mathrm{~mm}$ de largura de gengiva ceratinizada, e no grupo controle, menos de $2 \mathrm{~mm}$ de gengiva desta estrutura. Os resultados obtidos mostraram que, em áreas com menos de $2 \mathrm{~mm}$ de gengiva ceratinizada, havia maior acúmulo de placa e maior índice de exsudato inflamatório, a despeito do bom padrão de higiene bucal. Os parâmetros analisados mostraram, assim, que uma faixa mínima de gengiva inserida era necessária para a manutenção da saúde periodontal, pois áreas com menos de $2 \mathrm{~mm}$ de gengiva ceratinizada mostraram persistência de inflamação. Essas observações parecem indicar que a zona da gengiva ceratinizada influenciou o comportamento fisiológico do sulco gengival, a tal ponto que, mesmo com índice de placa negligível, em áreas com menos de $2 \mathrm{~mm}$ de gengiva ceratinizada, o comportamento dos tecidos é mais compatível com alterações patológicas do que fisiológicas.

NOVAES et al. ${ }^{53}$, em 1975, ao avaliarem casos de recessão gengival, relacionaram a quantidade de gengiva ceratinizada não somente à possibilidade do aumento da profundidade sulcular, mas também ao 
acréscimo submarginal de placa dentobacteriana, gerando condições favoráveis à inflamação. Isso estaria relacionado com margens de tecido de espessura menor, nas quais a densidade e a pobreza da organização do colágeno poderiam provocar potencial para a retratilidade do tecido em relação ao dente, justificando a necessidade de uma faixa adequada de gengiva ceratinizada para a manutenção das condições fisiológicas do eriodonto.

Os resultados do estudo de AINAMO; AINAMO1, em 1978, indicaram que, mesmo durante supra-erupção pronunciada dos dentes, tende a ocorrer deslocamento da margem do tecido gengival, enquanto a localização da junção mucogengival permanece constante, o que implica em aumento da gengiva ceratinizada e inserida.

Estudando a importância das dimensões fisiológicas do periodonto na dentística restauradora, MAYNARD JR.; WILSON ${ }^{46}$, em 1979, verificaram que a necessidade de faixa adequada de tecido ceratinizado para restauração bem-sucedida deve-se ao fato de que o epitélio ceratinizado e as fibras de tecido conjuntivo denso subjacente dissipam o stress tensional exercido pelo freio e pelas fibras musculares e protegem a margem gengival móvel livre da tensão. Afirmaram que pelo menos $3 \mathrm{~mm}$ de gengiva ceratinizada são necessários, se as margens restauradoras forem colocadas no sulco gengival. Também mencionaram que a espessura do tecido ceratinizado é adequada quando a sonda periodontal não pode ser vista através da margem da gengiva livre. Nestes casos, propuseram a criação cirúrgica de segmento mais espesso e substancial de gengiva ceratinizada em áreas submetidas a procedimentos restauradores intra-sulculares, numa inferência de que não só a largura mas também a espessura da gengiva ceratinizada são importantes. Em uma análise bastante elementar, é fácil compreender que sulco raso, forma e função normais estão obviamente associados à manifestação das distâncias biológicas, parecendo racional aceitar-se o postulado de MAYNARD JR.; WILSON ${ }^{46}$, que incluíram a quantidade de gengiva inserida como necessária para estabilizar a margem 
gengival e, portanto, sendo integrante das distâncias biológicas do periodonto marginal.

TREY; BERNIMOULIN ${ }^{76}$, em 1980, avaliaram a influência do aumento da faixa de gengiva ceratinizada em áreas consideradas inadequadas $(<1 \mathrm{~mm})$, pelo posicionamento de enxerto gengival autógeno livre na margem gengival. Observaram, após 6 e 12 semanas de avaliação, que, a despeito do aumento significante da faixa de gengiva ceratinizada $(p<0,05)$, mais nos sítios testes do que nos de controle, não houve diferenças em outros parâmetros clínicos, como sangramento à sondagem e fluxo de fluido gengival, exceto pela redução significativa $(p<0,05)$, nos dois grupos, do índice de placa. Vale ressaltar, porém, que no exame inicial os dentes considerados como controle (contra-laterais aos sítios experimentais) apresentavam faixa mais larga de gengiva ceratinizada, mas que mostrou tendência de redução com o tempo (3 meses). Além disso, os pacientes eram acompanhados freqüentemente e instruídos individualmente quanto à higienização.

O estudo longitudinal de DORFMAN; KENNEDY; BIRD ${ }^{21}$, em 1980, avaliou áreas com faixa estreita de gengiva ceratinizada, que receberam enxerto gengival autógeno livre, em relação a áreas que não foram tratadas (grupo controle), e verificaram que ambos os grupos não mostraram perda adicional de inserção. Entretanto, houve migração coronal da margem gengival com diminuição da recessão no lado que recebeu enxerto. $O$ fato de os autores terem controlado a higiene bucal em regime de periodicidade impediu a análise da resposta gengival em função da resposta agressiva da placa dentobacteriana.

Ao realizar estudo clínico e histológico em tecido normal e regenerado de cachorros, para avaliar o papel da gengiva ceratinizada na saúde gengival, WENNSTRÖM; LINDHE; NYMAN ${ }^{80}$, em 1981, induziram o desenvolvimento da doença periodontal nos animais através da introdução de ligadura de fio de algodão no interior do sulco gengival. No lado controle, um programa de limpeza cuidadosa foi realizado durante todo o período do 
experimento (270 dias), enquanto, no lado experimental, depois de 150 dias, os tecidos inflamados foram removidos cirurgicamente e mantidos sob controle de placa, diário, por 120 dias. No lado controle, a gengiva foi mantida inalterada em comparação à fase de periodontite. Subseqüentemente a excisão dos tecidos inflamados, uma nova unidade gengival se desenvolveu em muitos aspectos, semelhante à unidade controle. Além disso, na ausência de placa dentobacteriana o tecido regenerado esteve livre de sinais de inflamação, independentemente da quantidade de gengiva ceratinizada.

Em estudo clínico correlacionando à largura de gengiva inserida à prevalência de recessão gengival, TENENBAUM ${ }^{74}$, em 1982, avaliou 100 pacientes e não encontrou correlação entre higiene bucal e recessão gengival, higiene bucal e largura de gengiva inserida, condições gengivais e largura de gengiva inserida. Ressaltou que o papel do trauma de escovação e da largura adequada de gengiva inserida, na etiologia da recessão gengival, são questionáveis, sugerindo que a existência de uma zona estreita de gengiva inserida é conseqüência da recessão ao invés de causa.

Ainda nesse ano, WENNSTRÖM; LINDHE; NYMAN ${ }^{81}$, avaliaram o papel da gengiva ceratinizada no desenvolvimento de gengivite, associada à formação da placa dentobacteriana, em cachorros da raça beagle. No mesmo cão, foram criadas três diferentes situações clínicas: uma envolvendo uma zona larga de gengiva ceratinizada através de procedimento a retalho; outra envolvendo uma faixa de gengiva ceratinizada insuficiente ou ausente, através de procedimento de gengivectomia; e outra, usada como controle envolvendo, áreas com faixa normal de gengiva ceratinizada, nas quais nenhum procedimento cirúrgico foi realizado. Os exames histológico e clínico (índice de placa, índice gengival e índice de fluido gengival) mostraram que, na análise inicial, as três áreas apresentavam-se saudáveis. Após 40 dias de acúmulo de placa, todas as áreas apresentavam inflamação cuja extensão e localização não variavam significativamente, sugerindo que, na ausência de placa, não parecia haver 
necessidade de uma faixa mínima de gengiva ceratinizada para a manutenção da saúde gengival. Entretanto, o estudo também mostrou que, clinicamente, áreas com pequena faixa ou ausência de gengiva ceratinizada apresentavam sinais pronunciados de gengivite, enquanto áreas com largura normal (controle) e aumentada (grupo enxertado) apresentaram pequeno índice de inflamação tecidual.

Segundo ainda esta filosofia, WENNSTRÖM; LINDHE ${ }^{79}$, no ano seguinte, avaliaram o papel da gengiva inserida na manutenção da saúde periodontal. Para tanto utilizaram cães beagle, nos quais induziram doença periodontal no lado direito dos maxilares (experimental) durante 6 meses, por meio da introdução de fios de algodão colocados subgengivalmente ao redor da porção cervical dos dentes, de forma a facilitar o acúmulo de placa dentobacteriana. Assim, ocorreu a formação de processo inflamatório do tecido mole, após o que se seguiu remoção cirúrgica de toda a faixa de gengiva ceratinizada. Decorridos 4 meses com controle diário de placa, um enxerto gengival foi inserido em um dos quadrantes do lado experimental, enquanto o outro foi deixado sem enxerto. No grupo controle, sem enxerto e no lado contra lateral dos maxilares, os dentes foram mantidos com controle meticuloso e diário da placa dentobacteriana durante todo o período inicial de 6 meses. Neste ponto, em um dos quadrantes do lado controle foi excisada toda faixa de gengiva ceratinizada e inserida. A seguir, todos os grupos foram submetidos a exames clínicos em determinados intervalos de tempo, até o término do experimento 4 meses depois da realização dos enxertos. Para os autores, os resultados mostraram que, nos sítios submetidos a medidas de rigoroso controle de placa, a saúde gengival pôde ser estabelecida e mantida sem sinal de recessão da margem gengival ou perda de inserção independente de presença ou ausência de gengiva inserida, largura de gengiva ceratinizada ou altura do periodonto de suporte. Após a remoção cirúrgica de toda gengiva, todos os sítios bucais mostraram ganho de gengiva ceratinizada, porém a maioria das áreas apresentou falta de gengivainserida. Além disso, o enxerto de tecido gengival aumentou significativamente a largura da gengiva inserida e ceratinizada, mas não teve 
nenhum efeito óbvio na posição da margem gengival ou no nível de inserção. Resalta-se que não foi usado nenhum grupo no qual se permitiu a formação de placa.

ERICSSON; LINDHE ${ }^{24}$, em 1984, demonstraram, em cães da raça beagle, que, na presença de bandas ortodônticas cimentadas subgengivalmente, simulando restaurações intrasulculares, em áreas com gengivas ceratinizadas inadequadas, formação de placa subgengival, e que o infiltrado inflamatório se restringiu à região de gengiva livre onde havia uma faixa adequada de gengiva inserida, enquanto, nas áreas onde não existia quantidade suficiente de gengiva ceratinizada, em quase todos os casos, ocorreu perda adicional de tecido.

Preocupado com o valor da gengiva ceratinizada no comportamento periodontal marginal, KENNEDY et al. ${ }^{34}$, em 1985, estudaram, durante 6 anos, 32 pacientes apresentando, bilateralmente, dentes homólogos com faixa inadequada de gengiva inserida. De um lado, foi realizada cirurgia de enxerto gengival livre autógeno, enquanto do lado oposto não foi realizado nenhum procedimento cirúrgico, servindo como controle. Os pacientes foram acompanhados, em regime de manutenção, em intervalos de 3 a 6 meses ou menos, e, quando necessário, por período de 6 anos. O grupo controle não apresentou recessão adicional ou perda posterior de inserção, enquanto o grupo experimental mostrou redução da recessão e ganho de inserção clínica. Esses resultados sugeriram que seria possível manter saúde e inserção periodontal em pacientes controlados mesmo em áreas com uma faixa de gengiva inserida não satisfatória. No entanto, nesse mesmo trabalho, exames realizados em pacientes que deixaram de participar do controle de manutenção por período de 5 anos e que puderam ser avaliados após 6 anos, revelaram o reestabelecimento da inflamação gengival associada com perda adicional de inserção no lado controle (sem enxerto), enquanto os sítios experimentais se mantiveram estáveis.

Em 1986, KISCH; EGELBERG ${ }^{36}$ monitoraram seletivamente áreas gengivais, mostrando ausência de gengiva inserida combinada com 
mobilidade da margem gengival. Os pacientes haviam sido submetidos a tratamento de doença periodontal severa 10 a 15 anos anteriormente, principalmente através de procedimentos de gengivectomia. Foram comparadas 43 superfícies consideradas de risco (gengiva ceratinizada $\leq 1 \mathrm{~mm}$, ausência de gengiva inserida, mobilidade da margem gengival) com 36 superfícies de não-risco, nesses mesmos pacientes (gengiva ceratinizada $\geq 2 \mathrm{~mm}$, gengiva inserida $\geq 0,5 \mathrm{~mm}$, sem mobilidade da margem gengival). Durante o período de cinco anos de observação, as superfícies de não-risco mostraram tendência de diminuição da média da largura de gengiva ceratinizada, enquanto as superfícies consideradas de risco permaneceram inalteradas Não houve alterações das medidas de profundidade de sondagem em ambos os grupos. Ressaltam, assim, que este estudo falhou em demonstrar que superfícies gengivais vestibulares móveis e não inseridas seriam mais susceptíveis à quebra da homeostasia do periodonto do que superfícies inseridas.

No mesmo ano, com o propósito de monitorar mudanças longitudinais na porção da margem do tecido mole, WENNSTRÖM ${ }^{78}$ avaliou 26 sítios onde todo tecido gengival tinha sido removido cirurgicamente. O exame realizado 6 meses após o tratamento revelou que houve ausência total ou presença de pequena zona de gengiva inserida regenerada $(<1 \mathrm{~mm})$, enquanto 12 sítios foram mantidos como controle, por apresentarem largura adequada de gengiva inserida $(>1 \mathrm{~mm})$. Avaliações da higiene bucal, condições de gengiva, profundidade de sondagem, nível de inserção, margem gengival e largura da gengiva foram feitas no exame inicial e depois de 5 anos. Os resultados revelaram que, nos sítios-teste, um pequeno aumento da largura da gengiva ocorreu durante o período de estudo enquanto 7 das 26 superfícies mostraram crescimento coronal da margem gengival, e 2 sítios mostraram deslocamento apical da margem. No grupo controle, 3 sítios desenvolveram recessão acompanhada por redução da largura da gengiva. Esses achados sugeriram que, em pacientes que mantiveram controle de placa apropriado, a falta de zona adequada de 
gengiva inserida não resultou em incidência aumentada de recessões gengivais.

STETLER; BISSADA ${ }^{72}$ avaliaram, em 1987, os índices de placa, gengival, quantidade de fluxo de fluido gengival, profundidade de sondagem, sangramento à sondagem, nível de inserção e de perda óssea em sítios com e sem restaurações subgengivais, apresentando ou não, no mínimo, $2 \mathrm{~mm}$ de gengiva ceratinizada. Os resultados mostraram que dentes não restaurados não mostraram grau de inflamação gengival significante, mesmo em áreas com menos de $2 \mathrm{~mm}$ de gengiva ceratinizada, enquanto dentes restaurados mostraram maior grau de inflamação nas áreas com menos de $2 \mathrm{~mm}$ de gengiva ceratinizada, o que salientou a importância da quantidade suficiente de gengiva ceratinizada no comportamento homeostático do periodonto.

SCHLUGER et al. ${ }^{64}$, em 1990, propuseram usar uma faixa de $2 \mathrm{~mm}$ de gengiva ceratinizada, considerando ser este um fator crítico para o início da recessão gengival, avaliando também outros fatores, como idade, proeminência do dente no arco, planejamento de restaurações terapêuticas ou protéticas sub-sulculares, previamente a tratamento ortodôntico, monitoramento cuidadoso em casos de difícil decisão e aprofundamento de vestíbulo em pacientes desdentados. Salientaram, ainda, a possibilidade de variabilidade da distância intra-sulcular e do epitélio juncional, mantendo-se constante a área de inserção de fibras supra-cristais. Onde ocorreu invasão das distâncias biológicas mencionadas em áreas de gengiva fina e delicada, a recessão pôde ser rápida, enquanto em áreas de gengiva marginal espessa, a reabsorção demorou mais a se processar, levando de alguns meses a 1 ano ou mais, sugerindo potencial protetor da qualidade do tecido marginal.

Ao descrever as estruturas periodontais RAMFJORD; ASH JR. ${ }^{63}$, em 1991, descreveram a gengiva como o tecido conjuntivo fibroso que circunda os dentes e cobre a porção coronária do processo alveolar. A porção marginal foi denominada gengiva livre ou gengiva marginal, e seu limite 
coronário, margem gengival livre. A gengiva livre é inserida na superfície do dente pelo epitélio juncional, que forma a base do sulco gengival. Pode existir clinicamente, em alguns pacientes, uma ranhura gengival livre, que separa a gengiva marginal livre, em sua porção apical, da gengiva inserida, que seria a parte firme da gengiva, porque ela é firmemente fixada ao processo alveolar vestibular e lingual e ao colo dos dentes. Quanto à distribuição clinica da gengiva inserida, consideraram que a zona mais ampla é encontrada nas regiões anteriores, diminuindo dos caninos para a distal, estando a zona mais estreita da gengiva inserida no aspecto vestibular dos primeiros pré-molares inferiores, enquanto a mais larga está na região anterior superior. A largura da gengiva inserida tende a aumentar com a idade se não houver recessão gengival, pois parece que a posição da linha mucogengival relativa à borda inferior da mandíbula é constante, com o tempo, de modo que a gengiva inserida aumenta com a erupção compensatória dos dentes.

HASSEL ${ }^{31}$ relatou, em 1993, que a gengiva normal possui coloração rósea (rosa salmão ou coral) e está separada apicalmente da mucosa alveolar (usualmente de coloração vermelho-escura) pela linha mucogengival, a qual é mais ou menos evidente clinicamente, dependendo do grau de ceratinização e pigmentação da gengiva. Afirmou ainda que a largura coronoapical da gengiva inserida pode variar significativamente de um dente para outro e entre dentes de diferentes indivíduos, tendendo-se a tornar maior com a idade.

Já LÖE; LISTGARTEN; TERRANOVA ${ }^{43}$, em 1996, descreveram a gengiva como sendo parte da mucosa bucal que reveste os processos alveolares e as porções cervicais dos dentes. Ao dividi-la tradicionalmente em gengiva livre e inserida, consideraram que uma linha imaginária entre o fundo do sulco gengival e a superfície gengival seria a demarcação entre as duas gengivas. Descreveram ainda que, em dentes com erupção completa, encontra-se um orifício raso entre a margem gengival e a superfície do dente denominado sulco gengival e que a profundidade deste sulco em gengiva 
clinicamente saudável raramente excede 2 a $3 \mathrm{~mm}$. Contudo, esta medida pode diferir significantemente daquela do sulco gengival histológico e, por esta medida em locais estritamente normais ser desprezível em relação à largura total da gengiva inserida, sugeriram que não fossem mais usados os termos livre e inserida com relação à gengiva. Devido ao fato de a sonda periodontal não refletir precisamente a profundidade do sulco histológico, o termo profundidade de sondagem ou profundidade sondável do sulco gengival refletiria as medidas obtidas com maior precisão.

Numa explanação da importância do respeito às distâncias biológicas, CARRANZA; TAKEI $^{17}$, em 1997, consideraram essencial que houvesse pelo menos $3 \mathrm{~mm}$ de espaço entre a extensão mais apical da margem da restauração e a crista óssea alveolar, de forma a existir estrutura dental suficiente para a acomodação das fibras colágenas supra-alveolares e para propiciar 2 a $3 \mathrm{~mm}$ de relacionamento com epitélio crevicular (juncional e do sulco gengival). Nessas condições, consideraram que a localização da margem de coroas no nível subgengival correspondente à metade do sulco gengival clínico não resultaria em aumento da inflamação e formação de bolsa. $\mathrm{Na}$ associação com procedimentos restauradores, propuseram que o aumento na gengiva ceratinizada proporcionaria estabilidade para a gengiva marginal livre e para os tecidos gengivais circundantes, de modo que a restauração poderia ser colocada em um ambiente no qual a saúde gengival poderia ser mantida, aludindo à importância da presença de gengiva ceratinizada.

Em 1998, PASSANEZI et al. ${ }^{61}$, ao discutirem a relação da necessidade ou não de se ter alguma quantidade de gengiva ceratinizada para a manutenção de um equilíbrio homeostático do periodonto marginal, relataram alguns aspectos para que se pudesse compreender a função dessas estruturas (gengiva ceratinizada e mucosa alveolar), enfatizando a necessidade de uma relação proporcional entre a quantidade de gengiva ceratinizada e a mucosa alveolar, de modo que essa gengiva fosse capaz de neutralizar a tensão transmitida pela mucosa alveolar sob ação funcional da 
musculatura, sem produzir movimentação da margem gengival. Ao avaliarem trabalhos anteriores, como de LANG; LÖE ${ }^{38}$, concluíram que a existência de menos de $2 \mathrm{~mm}$ de gengiva ceratinizada $(1 \mathrm{~mm}$ de gengiva marginal livre e $1 \mathrm{~mm}$ de gengiva inserida), mesmo que o índice de placa fosse negligível, o comportamento dos tecidos seria mais compatível com alterações patológicas do que fisiológicas. Ainda ressaltando a importância dessas estruturas, questionaram o fato de que o índice de exsudato poderia estar alterado mesmo sem placa dentobacteriana, podendo traduzir a função da gengiva ceratinizada de permitir um grau de impermeabilidade relativa ao tecido nas proximidades do sulco gengival. Ao avaliarem a permeabilidade da mucosa alveolar, elucidariam o fato de o organismo reconhecer estímulos agressivos nessa região antes mesmo que tenham efetivamente invadido o meio interno e atuado nele, o que poderia gerar maior extravasamento de plasma nos tecidos, levando ao aumento da pressão hidrostática tecidual nas proximidades do epitélio juncional. Esclareceram, assim, a importância do papel das diferentes estruturas no mecanismo homeostático dos tecidos: a mucosa alveolar com a função de reconhecimento dos agentes agressivos e desempenho funcional, e a gengiva ceratinizada, tendo a função de melhorar o comportamento da área do sulco gengival, estabelecem assim, o equilíbrio da fisiologia do periodonto.

A espessura do periodonto, segundo MAYNARD JR. ${ }^{47}$, em 1998, apresentaria grande correlação com problemas mucogengivais. Existiriam quatro possibilidades, sendo que no sítio I a dimensão normal de tecido ceratinizado e o comprimento vestíbulo-lingual normal ou ideal do processo alveolar implicaria, clinicamente, uma zona de tecido ceratinizado de 3 a $5 \mathrm{~mm}$ e um tecido mais resistente à palpação, portanto mais espesso. Nessa condição clínica, uma zona adequada de gengiva ceratinizada separaria a zona marginal livre da gengiva, capaz de sofrer recessão, da zona móvel da mucosa alveolar. No tipo II, existiria um tecido ceratinizado mais fino associado a comprimento vestíbulo-lingual do processo alveolar, enquanto o tipo III apresentaria zona adequada de tecido ceratinizado e associado a comprimento fino do processo alveolar no sentido vestibular, resultando, 
clinicamente, em zona adequada de tecidos ceratinizados, permitindo a palpação das raízes. Já no tipo IV, existiria uma associação de tecido ceratinizado fino e gengiva fina, o que favoreceria, clinicamente, o processo de recessão da margem gengival na presença de pobre controle de placa e trauma local.

LINDHE; KARRING ${ }^{39}$, em 1999, descreveram que, didaticamente, a gengiva poderia ser dividida em gengiva livre e gengiva inserida. A linha divisória entre as duas é uma linha imaginária entre o fundo do sulco gengival e a superfície gengival visível oposta a ele. A gengiva inserida se estende apicalmente deste ponto até a junção mucogengival. A largura da gengiva inserida foi por ele considerada como importante parâmetro clínico, e não deveria ser confundida com a largura da gengiva ceratinizada porque esta última inclui também a gengiva marginal livre.

MENDONÇA ${ }^{48}$, em 2001, tendo como objetivo analisar a espessura dos tecidos moles com o uso do ultra-som SDM (técnica não invasiva), correlacionou-o com parâmetros já conhecidos para a análise das distâncias biológicas, como: profundidade de sondagem clínica manual, espessura da crista óssea, distância da margem gengival até o nível ósseo e o índice de sangramento à sondagem, na tentativa de determinar uma correlação mais precisa entre parâmetros já conhecidos das distâncias biológicas dos periodontos de proteção e sustentação. Concluiu que a presença de crista óssea fina aumenta a propensão de manifestação de sangramento gengival, devido à correlação com tecido gengival fino e com menor largura de gengiva ceratinizada, conforme anteriormente proposto por MAYNARD JR. ${ }^{47}$, alterando a homeostasia periodontal marginal. Houve correlação positiva da espessura, influenciando a formação das distâncias biológicas voltadas contra o dente. Existiu uma correlação estatisticamente significativa entre largura da mucosa ceratinizada e a distância da margem gengival à crista óssea, nos sítios que apresentavam espessura óssea normal. Quando na presença de índice de sangramento zero, correlações foram altamente significativas estatisticamente, ambas correlacionadas com 
a espessura da mucosa ceratinizada: a profundidade de sondagem e a largura da mucosa ceratinizada. Demonstrou, portanto, a necessidade de um equilíbrio entre periodonto de proteção e sustentação para um melhor equilíbrio homeostático do periodonto, pois, à medida que se correlacionou a quantidade e qualidade da gengiva ceratinizada com o volume de tecido mole sobre a crista óssea alveolar, entendeu-se a influência do desenvolvimento das próprias distâncias biológicas e conseqüentemente proteção ao complexo tecidual do periodonto de sustentação.

BARROSO ${ }^{8}$, em 2001, demonstrou melhora na relação tecido mole/tecido duro, diminuição da recessão e ganho de inserção clínica em pacientes que receberam enxerto gengival livre para aumento da faixa de gengiva ceratinizada. Os resultados obtidos demonstraram que os enxertos autógenos livres de gengiva produziram diminuição na recessão gengival e ganho no nível de inserção clínica, em consonância com o crescimento coronal da margem gengival, por "creeping attachment". As alterações produzidas nos níveis da margem gengival e da inserção clínica, em função da colocação de enxertos autógenos livres de gengiva apropriados, correlacionaram-se de maneira tal a não resultar em alteração significativa da profundidade do sulco gengival.

\subsection{Fluido Gengival}

Ao injetar fluoresceína intravenosamente, BRILL; KRASSE ${ }^{15}$, em 1959, demonstraram que nenhum outro tipo de epitélio oral normal permite a passagem de fluidos contendo tal substância, do ambiente interno para o externo. Foi sugerido, assim, que a permeabilidade do epitélio do sulco difere daquela de outros epitélios clinicamente saudáveis da cavidade oral.

Se matéria bacteriana ou outras partículas fossem introduzidas dentro do sulco gengival elas seriam expelidas em minutos de dentro do sulco, 
desde que não fossem retidas mecanicamente, segundo WAERHAUG; STEEN, em 1952 (apud CIMASONI ${ }^{18}$ ) e BRILL; KRASSE ${ }^{15}$, em 1959. Nessas condições, a quantidade de fluido se mostrou aumentada, indicando um efeito de lavagem, o que poderia representar uma parte importante do mecanismo de defesa local da gengiva.

LÖE; HOLM-PEDERSEN ${ }^{42}$, em 1965, avaliaram a taxa de fluxo de fluido gengival extra e intrasulcularmente em 43 pacientes com gengiva clinicamente normal, com e sem estimulação mecânica, através da mastigação de 8 gramas de parafina, por 10 minutos. Do total, 26 pacientes apresentavam inflamação gengival, enquanto em 8 pacientes a gengivite foi induzida pelo acúmulo de placa após suspensão das medidas de higiene bucal. Não houve exsudato de fluido extravascularmente, com ou sem estímulo mecânico, em pacientes com gengiva clinicamente saudável. A saída de fluido gengival foi observada intra-crevicularmente em 29 de 47 amostras obtidas de áreas não submetidas a estímulo mecânico, e em 7/29 casos após estímulo mecânico. O método extravascular também não foi capaz de identificar fluxo de fluido gengival em 29/49 casos com gengivite, enquanto o método intra-sulcular identificou saída de fluido gengival em 44/49 casos avaliados. Esses achados foram mais pronunciados nos casos de gengivite moderada. Nos casos de gengivite induzida, houve aumento do fluxo de fluido nos períodos de suspensão das medidas de higiene, correspondendo ao aumento do índice gengival, e foi máximo quando a gengivite estava clinicamente presente. Após a re-introdução das medidas de higiene, a taxa de fluxo de fluido gengival diminuiu. Esses resultados mostraram que o sulco gengival normal não apresenta fluxo de fluido gengival, que, por outro lado, está aumentado em áreas de gengiva inflamada, sugerindo que a saída de fluido gengival poderia representar um critério de definição entre gengiva saudável e inflamada.

Já EGELBERG ${ }^{22}$, em 1966, estudando efeito da administração sistêmica de histamina sobre os vasos sangüíneos de gengiva clinicamente saudável e cronicamente inflamada, de 30 cães, demonstraram que 
praticamente nenhuma reação ocorreu nos vasos sangüíneos de gengiva clinicamente saudável, enquanto a mesma dosagem causou aumento anormal de permeabilidade dos vasos de gengiva cronicamente inflamada. Isto foi observado pela formação de fluido gengival e pela marcação dos vasos sangüíneos com depósitos pesados de carbono, indicando que os vasos sangüíneos de gengiva inflamada são mais sujeitos a mostrar aumento de permeabilidade do que vasos de gengiva clinicamente saudável.

Ao avaliarem o fluxo de fluido gengival relacionado às mudanças inflamatórias no aspecto histológico, OLIVER; HOLM-PEDERSEN; LÖE ${ }^{56}$, em 1969, encontraram correlação positiva entre mensurações do exsudato gengival e os valores do índice gengival, comparativamente às mensurações de exsudato e densidade de células inflamatórias.

Segundo ORBAN; STALLARD ${ }^{57}$, em 1969, a produção de fluido gengival representaria um exsudato inflamatório ou um transudato especificamente alterado. Citam uma série de fatores motivadores de sua presença, tanto na gengiva inflamada quanto na gengiva saudável. Esses fatores incluíram mastigação, estimulação mecânica, mudanças hormonais, dietas e enzimas que poderiam afetar a quantidade de fluido, sem necessariamente afetar a condição inflamatória. Medidas do fluxo do fluido gengival foram feitas pela introdução de tiras de papel intra-crervicularmente por 3 minutos, removidas, deixadas secar e, subseqüentemente, imersas em solução de ninidrina a $2 \%$. Somente a área que absorveu o fluido gengival foi manchada, sugerindo que o fluxo do fluido gengival não provou ser um previsor preciso de inflamação gengival. Enquanto medida única de um paciente, os resultados poderiam ter pouco valor significativo. Medidas consecutivas, contudo, têm valor por relacionar as respostas dos tecidos gengivais ao ambiente e às condições, e a mudanças fisiológicas e patológicas.

ATTSTRÖM; EGELBERG ${ }^{6}$, em 1970, ao avaliarem a atração dos leucócitos por diferentes bactérias da placa, verificaram que os mesmos poderiam ser também encontrados em sulcos gengivais saudáveis. Foram 
observados leucócitos polimorfonucleares no sulco gengival de áreas saudáveis não irritadas mecanicamente, indicando que sua migração poderia ocorrer independentemente do aumento da permeabilidade vascular. Pela sua capacidade fagocítica e destrutiva, representariam um importante mecanismo protetor contra a extensão da placa dentro do sulco gengival.

No ano de 1973, EGELBERG; ATTSTRÖM ${ }^{23}$ compararam os métodos de coleta do fluido gengival intra e extra-sulculares propostos, respectivamente, por BRILL $^{14}$ e por LÖE; HOLM-PEDERSEN ${ }^{42}$. Os resultados mostraram que houve maior coleta de fluido pelo método intra-sulcular, mas esses resultados foram mais inconsistentes que o método de coleta extra-sulcular, que, por sua vez, mostrou menor variação entre as amostras, parecendo ser mais confiável, a despeito da menor quantidade de fluido observada.

Em 1974, ALFANO ${ }^{2}$ avaliou, através de medidas osmóticas, a produção de fluido gengival precoce ou pré-inflamatório. Propôs que a origem do fluido poderia se dar de duas maneiras: pela geração de um gradiente osmótico e pelo início de uma inflamação clássica. Com gengiva clinicamente saudável, pequenas quantidades de placa subgengival poderiam gerar quantidades limitadas de subprodutos macromoleculares, os quais seriam removidos pela superfície de absorção das células epiteliais de descamação ou através de fagocitose. Quanto mais macromoléculas estivessem presentes, maior seria a difusão intracelular para a membrana basal, que poderia ser considerada como principal barreira limitante. As macromoléculas se acumulariam na membrana basal, criando um gradiente osmótico e um fluxo de fluido gengival. Este fluido, modulado osmoticamente, não seria um exsudato inflamatório, mas em várias ocasiões poderia progredir a um exsudato inflamatório secundário.

O mesmo autor e sua equipe ${ }^{2}$, no ano seguinte, mostraram que subprodutos enzimáticos tóxicos e antigênicos de células bacterianas foram importantes mediadores no início da doença periodontal inflamatória. Conseqüentemente, a habilidade do epitélio sulcular gengival em minimizar 
a penetração destes subprodutos bacterianos dentro do tecido conjuntivo adjacente representa um mecanismo primário de defesa. Os resultados do estudo indicaram que fluxo de fluido gengival pré-inflamatório ou muito precoce poderia ser mediado osmoticamente, reiterando os achados anteriormente comentados.

ATTSTRÖM; BEER; SCHROEDER ${ }^{5}$, em 1975, realizaram estudo para caracterizar as características clínicas e descrever quantitativamente a composição estrutural normal dos tecidos gengivais de cães beagle. Os dados mostraram que o estabelecimento de medidas de higiene bucal a longo prazo resultaram em redução da inflamação gengival pré-existente. As medidas de fluxo do fluido gengival foram realizadas com tiras de filtro posicionadas no sulco gengival de forma a não adentrar o epitélio juncional, e pareceram indicar satisfatoriamente o momento no qual a saúde foi reestabelecida, definida como ausência de fluxo de fluido gengival. Apesar da ausência de fluxo de fluido gengival, a quantidade de leucócitos recolhidos por unidade gengival diminuía, mas nunca alcançava zero, o que implicou deduzirem que a migração de leucócitos e a produção de fluido eram dois fenômenos distintos. Desta forma, o fluxo de fluido gengival extrasulcular poderia ser considerado o único indicador disponível para caracterizar a normalidade dos tecidos gengivais. A contínua transmigração de granulócitos neutrófilos e a presença de linfócitos no epitélio juncional indicaria que, em um tecido gengival clinicamente normal, processos de defesa não cessam de operar.

Continuando seus estudos anteriores, em 1976 ALFANO et al. ${ }^{4}$ demonstraram que a aplicação tópica no sulco gengival de moléculas não tóxicas, antigênicas enzimáticas (por exemplo, albumina sérica) poderia dar início ao fluxo de fluido gengival derivado de um ambiente de osmolaridade passivo. O estudo foi realizado em pacientes considerados clinicamente saudáveis, apresentando índice gengival igual a zero $(\mathrm{Gl}=0)$. Os resultados mostraram que no lado onde foi aplicada albumina houve aumento do fluxo do fluido gengival, em relação à medida inicial de $84 \%$, depois de 3 horas, e 
mais de $100 \%$ após 6 horas. Entretanto, não se pode afirmar categoricamente que este resultado deveu-se ao gradiente de osmolaridade existente. O aumento do fluido poderia servir como substrato no qual enzimas microbianas ou do hospedeiro poderiam liberar amônia.

Um modelo matemático dos fatores que governam a distribuição do fluido através dos capilares foi desenvolvido por PASHLEY ${ }^{59}$, em 1976, de acordo com as seguintes considerações: a produção de fluido gengival foi moderada pela passagem do fluido dos capilares para os tecidos (filtração capilar) e pela remoção deste fluido intersticial pelos vasos linfáticos da gengiva (remoção linfática). Quando a produção do fluido dos capilares fosse maior do que a remoção linfática, o fluido se acumularia sob forma de edema ou deixaria a área como fluido gengival.

DANESHMAND; WADE ${ }^{19}$, em 1976, avaliaram a correlação entre o fluxo de fluido gengival e alterações macroscópicas (índice gengival, profundidade de sondagem) e microscópicas (integridade epitelial) com ou sem infiltrado de células inflamatórias no epitélio - Índice histológico - e análise morfométrica das células inflamatórias - Índice de Células Inflamatórias - em 30 sítios interproximais de pacientes adultos e com comprometimento periodontal. Houve correlação positiva pequena entre os índices histológicos e os índices gengival e de fluxo de fluido, sugerindo que os diferentes índices avaliam diferentes aspectos da resposta inflamatória.

MIYASATO; CRIGGER; EGELBERG ${ }^{50}$, em 1977, ao avaliarem as condições gengivais em áreas de largura mínima $(\leq 1 \mathrm{~mm})$ e apreciável ( $\geq 2 \mathrm{~mm}$ ) de gengiva, na superfície vestibular, com ausência de placa de prémolares inferiores em 16 estudantes ou membros da faculdade de Odontologia, não encontraram diferenças significativas na produção de fluido gengival. Foram avaliadas a quantidade de fluido gengival extravasada e a inflamação clínica baseada em alteração de cor e/ou edema e sangramento à sondagem. Os resultados mostraram que em ambos os casos houve a saída de mínima quantidade de fluido gengival, bem como ausência de inflamação gengival. Após a suspensão das medidas de higiene bucal por 
25 dias, os resultados mostraram aumento dos índices de placa, de exsudato gengival e de inflamação gengival, nos dois grupos.

Ao avaliarem a permeabilidade do epitélio sulcular, FINE; STUCHELL ${ }^{26}$, em 1977, demonstraram que, em seres humanos, a passagem de partículas de látex fluorescente através do sulco gengival para o tecido conjuntivo era elevada em áreas altamente inflamadas, quando comparadas com áreas de baixa inflamação. Foram encontradas 50 vezes mais partículas no tecido conjuntivo do grupo com alto índice gengival e taxa de fluxo de fluido, comparativamente ao grupo apresentando baixo índice gengival e de fluxo de fluido. Entretanto não houve diferença estatisticamente significativa no epitélio, o que poderia explicar a redução da função de barreira da membrana basal, nos pacientes com alto índice gengival e de fluxo de fluido.

POULSEN; HOLM-PEDERSEN; KELSTRUP ${ }^{62}$, em 1979, demonstraram que dos métodos usados tradicionalmente para avaliar o desenvolvimento de placa e gengivite, incluindo índices de placa gengival, de sangramento e de fluxo de fluido gengival (IP, GI, IS, FG), a medida do exsudato gengival foi a mais eficiente, visto que com sua utilização se faz necessário um menor número de pacientes para se conseguir resultados confiáveis.

Considerando a controvérsia existente, relativa ao fluido de fluxo gengival e a extensão clínica e histológica do processo inflamatório, em 1979, SHAPIRO; GOLDMAN; BLOOM ${ }^{65}$ avaliaram 45 pacientes não submetidos à terapia periodontal. As áreas selecionadas foram avaliadas clinicamente pelo índice gengival, e a coleta de fluido gengival foi alcançada pelo posicionamento de tiras de papel absorvente, 30 segundos após a secagem no orifício do sulco gengival, durante 1 minuto. Após a análise clínica, o tecido foi removido por biópsia e secção histológicas, que foram avaliadas. A quantidade de exsudato sulcular obtida foi comparada ao grau de inflamação histológica, não existindo diferenças estatisticamente significantes entre os grupos quando a quantidade de exsudato sulcular 
obtido foi comparado à avaliação clínica da inflamação determinada pelo índice gengival de Löe. Houve diferença estatisticamente significante entre os grupos.

CIMASONI $^{18}$, em 1983, ao avaliar a vasculatura e o fluido gengival, encontrou que a região do sulco gengival é provida de um aparato sanguíneo intenso, com alta taxa de renovação celular, percebendo que a capacidade de resposta aos menores estímulos se faz de maneira intensa e periódica. Em gengiva humana clinicamente saudável, uma área variavelmente pequena de tecido conjuntivo infiltrado pode ser vista, e muito pouco fluido pode ser coletado na ausência de irritação. Inicialmente, o fluido continha uma pequena concentração de proteínas, podendo representar um líquido intersticial gerado, localmente, por um gradiente osmótico, como resultado de permeabilidade aumentada dos vasos gengivais. Este poderia progredir para um exsudato inflamatório clássico, contendo quantidades maiores de proteínas. Os epitélios sulcular e juncional são permeáveis a uma variedade de substâncias, mas pouco se sabia até a época como a permeabilidade poderia ser influenciada pela integridade relativa ou pelo grau de inflamação da gengiva marginal.

SIEGEL ${ }^{66}$, em 1984, ressaltou que uma das funções primárias da mucosa oral seria proporcionar uma barreira que protegesse os tecidos subjacentes, tanto da entrada de substâncias endógenas quanto exógenas presentes na cavidade oral. Tal função de barreira também seria importante na direção reversa, prevenindo a perda de material dos tecidos subjacentes dentro da cavidade oral. Segundo o autor, sendo esta uma barreira imperfeita, muitas substâncias de fato a atravessam, mesmo sob circunstâncias normais; além disso, a taxa de penetração de substâncias através da mucosa oral podem ser influenciadas por uma variedade de fatores de ocorrência normal ou patológica.

BICKEL; CIMASONI; ANDERSEN ${ }^{11}$ relataram ser comumente aceito em 1985 que quase nenhum fluido poderia ser coletado de gengiva 
humana clinicamente saudável com o método preconizado por LÖE; HOLM-PEDERSEN ${ }^{42}$. Contudo, mostrou em seu trabalho que com a administração de fluoresceína duas horas antes da coleta de fluido a pacientes considerados clinicamente saudáveis, houve marcação em todas as tiras de papel posicionadas na borda do sulco gengival. Esta discrepância poderia ser atribuída à falta de critérios rigorosos na determinação de saúde gengival e à falta de técnicas de amostragens padronizadas. O estudo mostrou que pequenas quantidades de fluido puderam ser recuperadas dos sulcos depois de acúmulo de placa dentobacteriana por períodos tão curtos quanto 12 horas. Sinais clínicos de inflamação da margem gengival não puderam ser detectados durante este período. Esses resultados mostraram que o fluido inicial que aparece no sulco depois de um pequeno estímulo pela placa dentobacteriana, na ausência de sinais clínicos de inflamação, suportaram os critérios definidos por ALFANO², em 1974, segundo os quais um transudato gerado passivamente poderia se acumular no sulco clinicamente saudável.

LAMSTER $^{37}$, em 1992, ao avaliar a resposta do hospedeiro no fluido gengival (GCF) verificou que variáveis clínicas tradicionais têm valores limitados como indicadores para progressão futura da doença. Propôs que a avaliação diagnóstica baseada em produtos do hospedeiro observados no fluido gengival estaria entre as novas abordagens diagnósticas mais estudadas. Comentou, por exemplo, que níveis persistentemente elevados da enzima lisossomal B glucoronidase no fluido gengival foram correlacionadas à perda de inserção clínica.

Ao avaliar a presença da amilase salivar no fluido gengival, SMITH; CAMPS $^{70}$, em 1993, expressaram preocupação com a contaminação do fluido gengival pela saliva, pela placa subgengival e por sedimentos salivares, a despeito dos cuidados meticulosos de lavagem e secagem realizados nas áreas a serem coletadas por operadores experientes. Contudo, a avaliação precisa da quantidade de saliva existente no fluido gengival coletado do sulco através do ensaio da amilase não seria prático, 
mesmo se a contribuição da placa dentobacteriana e de sedimentos salivares pudessem ser eliminados, uma vez que muitos fatores afetam os níveis salivares da amilase. Entretanto, maior volume de fluido gengival foi anotado quando a quantidade de saliva no fluido aumentou. Houve forte correlação positiva entre volume e quantidade de amilase (e assim de saliva) no fluido gengival de pacientes saudáveis, mas somente uma fraca correlação entre estes parâmetros no fluido gengival de pacientes com periodontite.

Em 1995, MACPHEE; COWLEY ${ }^{44}$ ressaltaram a importância do fluido gengival e de elementos celulares no mecanismo de defesa do periodonto marginal na preservação da integridade fisiológica do sulco gengival. Segundo os autores, as evidências sugerem que o fluido gengival seja fator importante no governo da ecologia da população bacteriana do sulco e da placa subgengival em particular.

MARANGANI et al. ${ }^{45}$, em 1997, avaliaram a utilização de diferentes testes diagnósticos e concluíram que o fluido do sulco gengival é um exsudato inflamatório e que sua presença poderia permitir a identificação de respostas inflamatórias e imunológicas do hospedeiro. Ainda, propuseram que sua monitoração apresentaria praticidade quanto à realização, podendo ser realizado no próprio consultório.

CARRANZA; BULKACK ${ }^{16}$, em 1997, relataram que o epitélio sulcular que reveste o sulco gengival tem o potencial de ceratinização se for rebatido e exposto à cavidade bucal ou se a microbiota bacteriana do sulco for totalmente eliminada, o que sugeriu que a irritação local do sulco poderia dificultar ou impedir a ceratinização. $O$ fato de que o epitélio sulcular agiria como uma barreira semipermeável, onde produtos bacterianos prejudiciais passariam para dentro da gengiva, e onde o fluido tissular poderia ser exsudado para dentro do sulco como mecanismo de defesa local, destaca sua importância na tentativa de se manter o equilíbrio homeostático do periodonto. 
KINANE; LINDHE ${ }^{35}$ alertaram para o fato de muitas vezes a gengiva clinicamente sadia não progredir para condição de doença, apesar de enfrentar a agressão microbiana,provavelmente devido a fatores defensivos, dentre eles o fluxo positivo do fluido do sulco gengival. Tal fator poderia remover os microorganismos e seus produtos nocivos.

FABRO et al. ${ }^{25}$, ao avaliarem, em 2001, a transição das fases entre saúde e inflamação no nível gengival, mostraram que modificações precoces do tecido, incluindo, mudanças microvasculares e dinâmica do fluido devido à resposta do hospedeiro a agentes inflamatórios seriam, por si só, marcadores potenciais do risco para o desenvolvimento de uma doença mais severa. Seria importante, segundo os autores, diagnosticar condições inflamatórias precocemente, identificando os sítios de risco. Afirmaram que a mensuração da pressão do fluido intersticial gengival com a técnica de micropipetas padronizadas poderia, possivelmente, servir como uma ferramenta de diagnóstico para avaliar a inflamação do tecido, mesmo na ausência de outros sinais clínicos.

\subsection{InfluÊnCIA da Mastigação na Produção do Fluido Gengival}

O efeito da mastigação foi investigado por BRILL ${ }^{14}$, em 1959, em um grupo de enfermeiras que mostravam margens gengivais clinicamente saudáveis, por meio da técnica de coleta de fluido gengival com tiras de papel colocadas intrasulcularmente, até que se encontrasse pequena resistência. A quantidade de fluido gengival medida nas pontas do filtro de papel mostrou-se significativamente aumentada sob a influência da mastigação de parafina por 10 minutos. Quando estruturas gengivais fossem estimuladas pela mastigação, o efeito antimicrobiano poderia ser aumentado porque o estímulo mecânico do plexo vascular gengival estimularia o escape de fluido dos vasos, e o plasma conteria várias substâncias antimicrobianas, 
que estariam iniciando o processo de defesa. Assim, uma variedade de fatores de defesa humoral poderia ser mobilizada pela mastigação vigorosa, com participação em ambos os lados da cobertura epitelial do sulco gengival. Estes sítios seriam equipados desta forma para cuidar quimicamente de bactérias e toxinas invasoras, e a neutralização local de tais substâncias poderia, portanto, ser melhorada consideravelmente pela mastigação.

Parece importante mencionar-se a existência das chamadas fibras oxitalânicas do ligamento periodontal, dispostas da superfície do cemento à parede dos vasos sangüíneos, como exposto por FULLMER; LILLIE, em 1958 (apud TERRANOVA; GOLDMAN; LISTGARTEN ${ }^{75}$ ) e por FULLMER $^{27}$, em 1959.

A hipótese de que o sistema oxitalânico poderia constituir um mecanismo receptor, que regula o fluxo vascular de acordo com movimentos funcionais dos dentes, foi proposta por $\operatorname{SIMS}^{69}$, em 1975. Como extensão deste conceito, o autor postulou que a associação vascular oxitalânica poderia contribuir, como resultado do comportamento fásico do dente, para uma forma de ajuste (mediação) eletromecânico das paredes dos vasos periodontais.

JOHNSON; PYLYPAS ${ }^{33}$, em 1992, ao avaliarem a distribuição morfológica das fibras elásticas no ligamento periodontal de ratos, atribuíram, em parte, propriedades elásticas às fibras oxitalânicas existentes no ligamento periodontal e não a outros tipos de fibras elásticas antes descritas. O trabalho da malha das fibras oxitalânicas provavelmente contribuiria para dar suporte ao dente e para manter a homeostasia periodontal por dissipação das forças de mastigação e manutenção da potencialidade funcional.

GOIRIS ${ }^{29}$, em 1999, descreveu a presença das fibras oxitalânicas no ligamento periodontal humano, circundando as raízes dos dentes, 
localizadas abaixo do epitélio juncional, na região cervical e inseridas no cemento radicular em direção aos vasos sangüíneos do ligamento periodontal, agregando-se ao redor destes na forma de um plexo com orientação predominantemente oclusoapical. Quanto à função, houve correlação entre o aumento das forças oclusais recebidas por um dente e a sua quantidade, e existiria também uma associação das fibras oxitalânicas com os vasos sangüíneos e linfáticos do ligamento periodontal, dando suporte, além de permitirem a desobstrução destes quando sofrerem pressões. Desta maneira, como o ligamento periodontal apresenta um sistema proprioceptivo que responde a diferentes estímulos, as fibras oxitalânicas representam um mecanismo regulador do fluxo vascular, de acordo com movimentos funcionais dos dentes.

PASSANEZI; SANT'ANA ${ }^{60}$, em 1999, ressaltaram o fato de que a força mastigatória exercida em sua plenitude durante a trituração dos alimentos nos molares tem o máximo de transmissão de forças para o periodonto de sustentação dos dentes envolvidos. As forças oclusais que atuam sobre os dentes poderiam ser geradas durante a função normal, como a mastigação e a deglutição, sendo assim denominadas de forças funcionais. Essas atividades dinâmicas resultariam numa série de estímulos influentes no comportamento homeostático do periodonto de sustentação. Desse modo, quando o dente fosse movimentado no alvéolo sob ação de forças como a mastigação, fibras oxitalânicas transmitiriam esse estímulo para a parede dos vasos sangüíneos, permitindo, dessa forma, que o organismo pudesse controlar o fluxo sangüíneo necessário ao suprimento metabólico tissular e ao estabelecimento do mecanismo hidráulico de sustentação do dente no alvéolo. 


\subsection{Participação do Paciente no Controle de Fatores Bacterianos}

Porque a manutenção da homeostasia do periodonto marginal depende de cuidados profissionais periódicos, foi realizada revisão da literatura no sentido de se averiguar o quanto se consegue de "compliance", ou seja, de adesão dos pacientes aos programas de manutenção periodontal.

Em 1983, WILSOM JR. et al. ${ }^{84}$ estudaram o comportamento de pacientes submetidos a tratamento periodontal e colocados em regime de manutenção. Para tanto, avaliaram a freqüência (em \%) de retorno dos pacientes a visitas agendadas em clínica privada. Os resultados obtidos mostraram que $84 \%$ dos pacientes não retornaram regularmente às visitas agendadas. Além disso, 1/3 dos pacientes estudados não retornaram a nenhuma manutenção, o que representou mais que o dobro do número de pacientes que concordaram com seu chamamento posterior. Apenas um pequeno número dos pacientes (16\% em 8 anos) mantiveram o intervalo sugerido pelos autores.

Em estudo conduzido entre 1983 e 1986 para analisar o grau de cooperação dos pacientes com as visitas de manutenção, MENDOZA; NEWCOMB; NIXON ${ }^{49}$, em 1991, não encontraram diferenças significativas em relação a idade, sexo, número de dentes perdidos, quantidade de placa ou severidade periodontal entre pacientes colaboradores e não colaboradores. Existiam mais fumantes entre os pacientes não colaboradores do que colaboradores. Em contraste, os pacientes mais colaboradores tinham melhor cobertura de planos odontológicos, e a maioria havia feito cirurgia durante o tratamento. Apenas $36 \%$ dos pacientes inicialmente tratados mantiveram seu retorno no final de 1989, com a maior perda de pacientes no primeiro ano de terapia de suporte (42\%). A perda anual decrescia no ano subseqüente para $10 \%$ daqueles que sobravam em cada ano, indicando que o paciente é mais passível de continuar 
cooperando se este comparecer pelo menos no primeiro ano de terapia de suporte.

Em 1993, BERNDSEN; EIJKMAN; HOOGSTRATEN ${ }^{10}$, ao avaliaram a adesão de pacientes ao tratamento de manutenção proposto por 38 periodontistas e seus higienistas mais experientes, sugeriram que os periodontistas tendem a dar a mesma informação e instrução aos pacientes, independentemente do seu nível de cooperação, enquanto os higienistas adaptaram sua informação ao nível de cooperação do paciente. Além disso, eles conseguiram determinar com mais facilidade o nível de adesão do paciente colaborador através de questionamento sobre a sua adesão às recomendações, fatores importantes quando se quer elevar o percentual de adesão aos programas de manutenção.

WILSON JR.; HALE; TEMPLE ${ }^{84}$, em 1993, reportaram dados de pacientes por um período de 5 anos e mediram os esforços para melhorar a adesão em uma clínica periodontal privada. Estes esforços incluíram tentativa de simplificação da adesão, manutenção dos registros, informação aos pacientes sobre as conseqüências da não-adesão e identificação dos não-colaboradores antes que a terapia fosse iniciada. Os resultados foram medidos em relação a um grupo similar estudado em um trabalho prévio ${ }^{83}$ dentro da mesma clínica e publicado em 1983. Achou-se um aumento de 16\% em 1984 para 32\% em 1991 de adesão completa ao programa de manutenção, devido, provavelmente, aos esforços para a adesão executados na clínica e a outros fatores tais como aumento na percepção pública das necessidades dentais. Apesar de o trabalho sugerir que com algumas medidas ainda seria possível aumentar ainda mais a adesão dos pacientes aos programas de manutenção, este percentual ainda foi considerado baixo.

$\mathrm{BAKDASH}^{7}$, em 1994, analisou a prática de higiene bucal do paciente como fator de risco para o início das lesões de periodontite, relatando a necessidade da combinação da higiene bucal do paciente com a instrumentação profissional, para a manutenção da saúde bucal. Pacientes 
recebendo terapia inicial de suporte por 5 anos ou mais, após a terapia inicial exibiram progressão mínima na perda de inserção e alto grau de preservação dental. Diante disso, parece razoável que, embora a pobre higiene bucal permaneça sendo um fator de risco, a cooperação do paciente e o retorno às visitas no consultório para suprir estas deficiências seria necessário. Afirmou, entretanto, baseado em dados da literatura, que o grau de cooperação dos pacientes era baixo, variando entre $16 \%$ e $36 \%$.

DEMETRIOU; TSAMI-PANDI; PARASHIS ${ }^{20}$, em 1995, verificaram que apenas $27,4 \%$ dos pacientes avaliados cooperaram completamente com a terapia periodontal de suporte estabelecida até o final do estudo, citando que a taxa de terapia periodontal de suporte tende a decrescer durante os 2 primeiros anos, tendendo a se estabilizar posteriormente. Os resultados deste estudo confirmaram que a cooperação à terapia periodontal de suporte em consultórios privados está longe de ser ideal.

WEINSTEIN et al. ${ }^{77}$, em 1996, ao analisarem a interação psicológica em pacientes com pobre adesão aos programas de manutenção, avaliaram várias técnicas de modificação de comportamento. Dados coletados sobre um período de 3 meses indicaram que o autogerenciamento comportamental mais o reforço positivo aumentaram a adesão do paciente significativamente. As implicações para novas pesquisas foram discutidas em termos da análise de custo e de cada componente do procedimento, para o paciente e o profissional, em termos de tempo, dinheiro e esforço requerido, o que talvez explicasse os percentuais hoje baixos dos programas de manutenção.

Segundo PASSANEZI et al. ${ }^{61}$, em 1998, se o controle de manutenção permite manter saúde periodontal sem inflamação aparente, isto se deve ao fato de o controle do profissional ser eficiente na preservação da higiene bucal. Se é possível com uma faixa adequada de gengiva ceratinizada, eficácia na prevenção da formação de placa dentobacteriana, isso tornaria menos crítico o programa de manutenção, ao mesmo tempo em que a saúde seria mais facilmente preservada. 
NOVAES JR.; NOVAES JR. ${ }^{54}$, em 1999, avaliaram durante 5 anos 874 pacientes que receberam tratamento periodontal, cirúrgico e nãocirúrgico. Os resultados obtidos mostraram que $46,8 \%$ de pacientes participaram da terapia periodontal de suporte. Num segundo momento, estes autores, em 2001, acompanhando estes mesmos 874 pacientes por 10 anos, avaliaram a relação entre idade, sexo, tratamento cirúrgico e nãocirúrgico. Encontraram, no grupo cirúrgico, que $43,9 \%$ dos pacientes não retornaram à clinica para as visitas de manutenção, enquanto no grupo nãocirúrgico esta taxa subiu para $53,2 \%$, o que talvez sugerisse uma maior conscientização do problema de saúde periodontal do paciente submetido à cirurgia.

WILSON JR. ${ }^{82}$, em 1996, ao avaliar o papel da cooperação (compliance) dos pacientes com terapia periodontal, ressaltou que, mesmo nos estudos mais otimistas, a taxa de adesão completa aos métodos de higiene propostos foi menor que $50 \%$. Pacientes em programas baseados nas universidades mostraram taxa de não-adesão entre 11 e 45\%, enquanto em consultórios periodontais privados a adesão completa é vista em somente $1 / 3$ dos pacientes ou menos. 
3 PROPOSIÇÃO 


\section{PROPOSIÇÃO}

Com base nos estudos realizados, o objetivo deste trabalho é avaliar o comportamento homeostático do sulco gengival em função da avaliação da quantidade de gengiva ceratinizada, direcionando-se a análise para a verificação de variações na quantidade de fluido gengival produzido pelo ato da mastigação de alimentos naturais, que permitam avaliar:

- influência da mastigação no comportamento homeostático do sulco gengival;

- influência da quantidade de gengiva ceratinizada na saída do fluido gengival. 
4 MATERIAL E MÉTODOS 


\section{MATERIAL E MÉTODOS}

\subsection{Seleção dos Pacientes}

Para o desenvolvimento da pesquisa foram selecionados 16 pacientes que apresentavam boas condições de saúde geral, bom padrão de higiene bucal e ausência de doença periodontal nos sítios avaliados, que apresentassem, em dentes pré-molares e molares homólogos, faixa de gengiva ceratinizada de $2 \mathrm{~mm}$ ou mais (grupo experimental) e inferior a $2 \mathrm{~mm}$ (grupo controle). Não houve ainda distinção de raça ou sexo para a seleção dos pacientes. Os pacientes eram não fumantes e não apresentavam sinais suspeitos de oclusão traumatogênica.

O trabalho foi submetido a apreciação e aprovado pelo Comitê de Ética em Pesquisa da Faculdade de Odontologia de Bauru, Universidade de São Paulo, sob o n.10/2002. Os pacientes foram instruídos quanto à natureza da pesquisa e, após darem seu Consentimento Livre e Esclarecido, foram selecionados para o estudo.

Foram excluídos do estudo aqueles que apresentaram alterações sistêmicas, gestantes, aqueles que fizeram uso de medicamentos controlados nos 6 meses precedentes à pesquisa ou os que fizeram uso de antibióticos nos 3 meses anteriores, mais aqueles que apresentaram sinais clínicos de inflamação gengival nas áreas a serem avaliadas.

Inicialmente, os pacientes foram avaliados quanto aos seguintes parâmetros clínicos:

- Índice de placa bacteriana (SILNESS; LÖE ${ }^{68}$ ); 
- Índice de sangramento sulcular (MÜLHEMANN; $\mathrm{SON}^{51}$ );

- Profundidade de sondagem;

- Quantidade de gengiva ceratinizada;

- Quantidade de fluido gengival.

A avaliação clínica foi realizada por operador único, obtendo-se inicialmente o total de 384 medidas em 32 dentes examinados, nos 16 pacientes.

\subsection{Desenho Experimental}

Após o exame inicial, todos os pacientes receberam medidas de instrução de higiene bucal e, quando necessário, foram submetidos a raspagem e alisamento radicular, polimento e remoção de fatores de retenção de placa, tais como próteses mal adaptadas e restaurações insatisfatórias como método de padronização da amostra.

A avaliação dos parâmetros clínicos selecionados seguiram critérios aceitos e divulgados na literatura, respeitando os princípios a seguir enunciados:

- Índice de placa bacteriana: preconizado por SILNESS; LÖE ${ }^{68}$, segundo os quais $\mathbf{0}$ significa ausência de placa na área gengival; 1 significa uma película de placa aderida à margem gengival livre e à área adjacente do dente (a placa pode ser reconhecida no local apenas por aplicação de soluções evidenciadoras ou correndo-se uma sonda pela superfície do dente); 2 significa acúmulo moderado de depósitos moles dentro da bolsa gengival ou sobre o dente e margem gengival, o que pode ser visto a olho nu; 3 significa abundância de matéria mole dentro da bolsa gengival e/ou na margem gengival e na superfície adjacente do dente. 
Os pacientes que no primeiro exame exibiram índice 1 foram submetidos a reforço na instrução de higiene bucal, de modo que no momento da coleta dos dados o índice encontrado foi $\mathbf{0}$. Nenhum outro escore foi detectado nos demais pacientes (Figura 1).

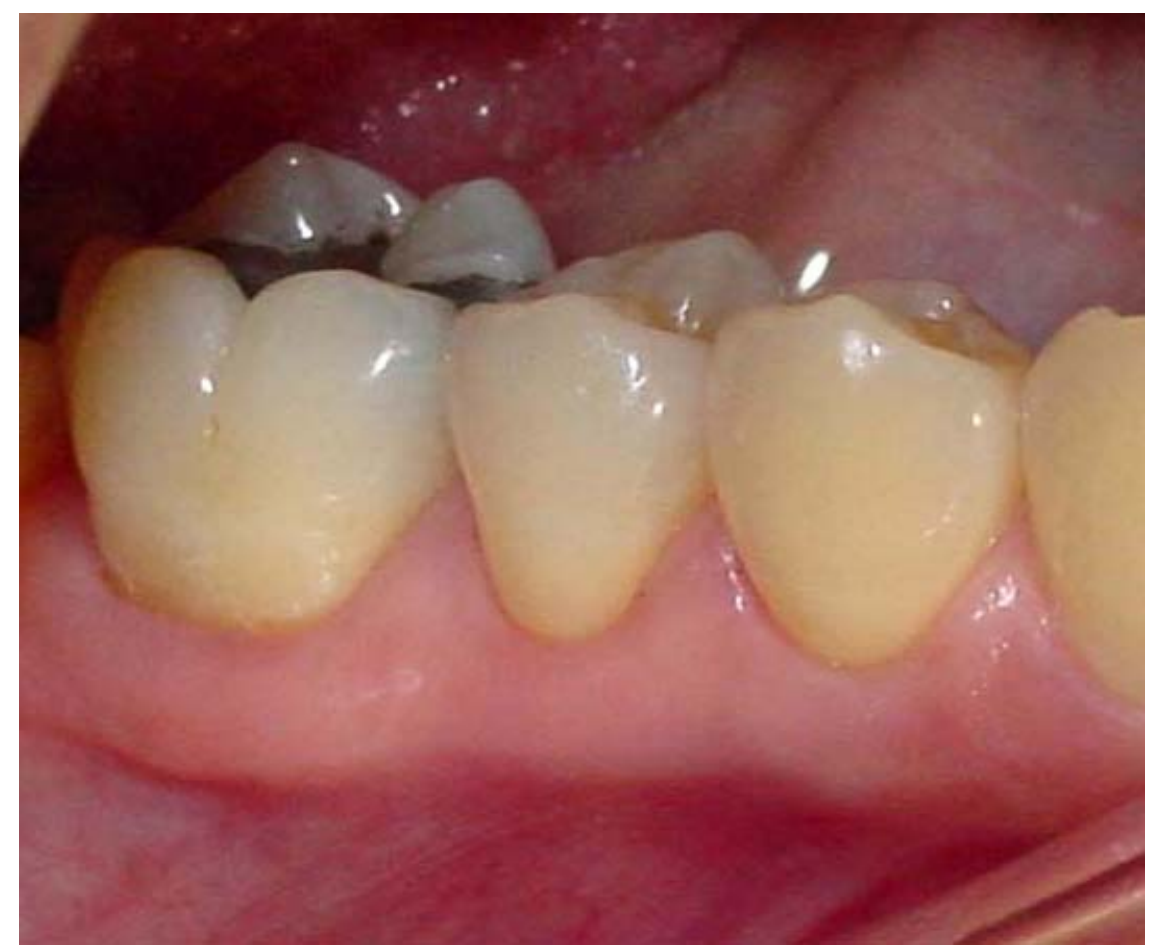

FIGURA 1 - Vista clínica da amostra do grupo experimental ( $\geq 2 \mathrm{~mm}$ de gengiva ceratinizada) Pode-se identificar o índice de placa $\mathbf{0 .}$

- Quantidade de gengiva ceratinizada: foi medida por meio da coloração dessa estrutura com solução de Schiller. O uso da tintura do complexo mucogengival com tal solução, que tem alto conteúdo de glicogênio, provoca reação iodo positiva na mucosa alveolar, enquanto o tecido ceratinizado mostra reação iodo negativa devido ao baixo teor de glicogênio. Este método parece ser mais preciso uma vez que a faixa de gengiva ceratinizada torna-se visualmente distinguível após a tintura, o que facilita a sua mensuração com o paquímetro digital utilizado. A proposta de GUGLIELMONI et al. ${ }^{30}$, segundo os quais não existiriam diferenças na mensuração das estruturas com e sem evidenciação por tintura, não foi

* Model n.SC-6, Mitutoyo Corporation, USA. 
levada em consideração porque, nesse trabalho, as medidas foram processadas por apenas dois examinadores.

A largura da gengiva ceratinizada foi medida com paquímetro digital (Figura 2A), expressa como sendo a distância, em milímetros, da margem gengival até a linha mucogengival. As medidas foram realizadas na face vestibular dos dentes avaliados de acordo com o ponto mais crítico, ou seja, nos dentes com menos de $2 \mathrm{~mm}$ de gengiva ceratinizada, a medida foi tomada na menor largura existente na área e, nos dentes com mais de $2 \mathrm{~mm}$ de gengiva ceratinizada, a medida foi tomada na faixa de maior largura presente (Figura 2B).
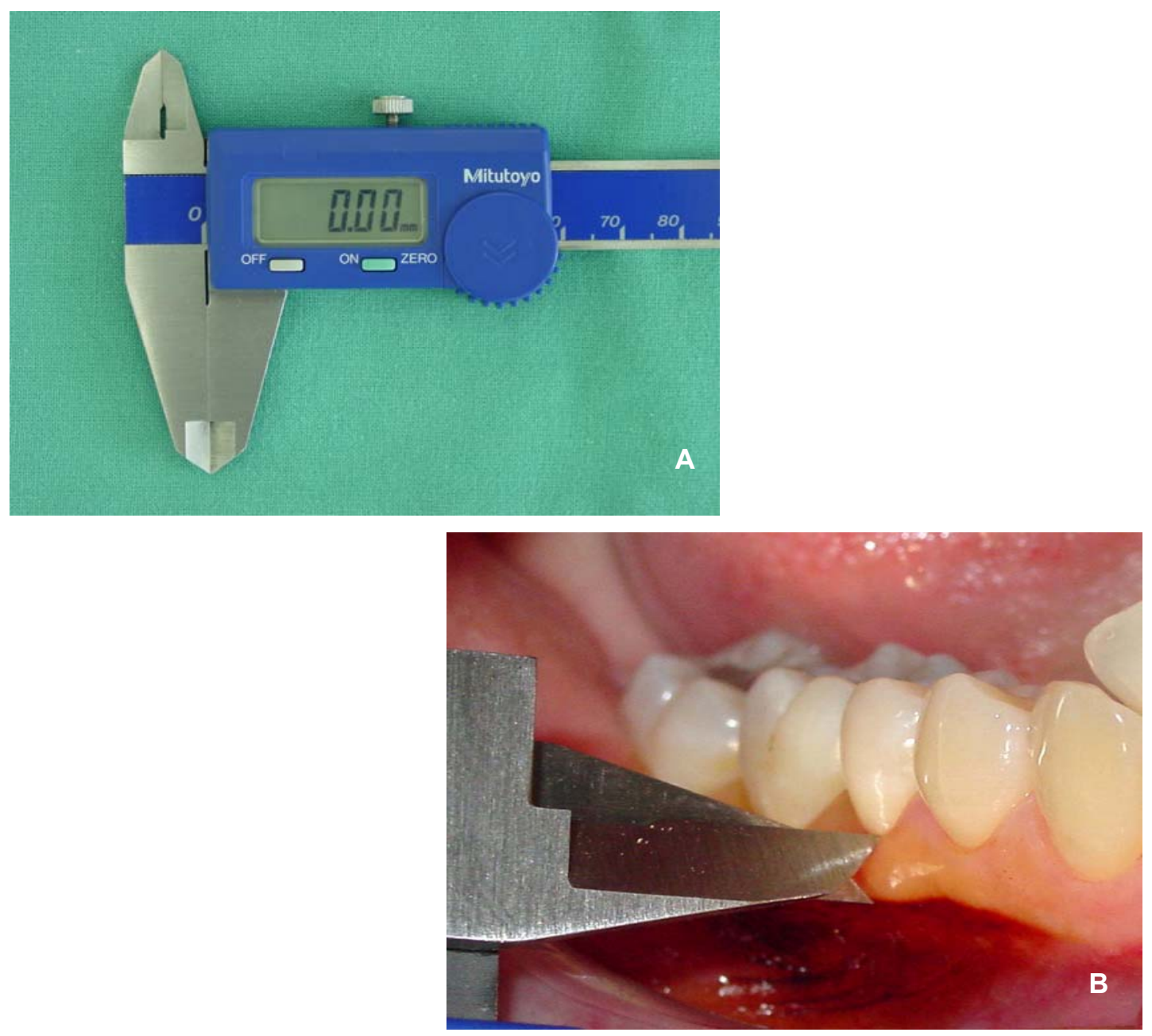

FIGURA 2 - Vista e metodologia do paquímetro digital

A) vista do paquímetro digital usado; B) ilustração da metodologia de mensuração da quantidade de gengiva ceratinizada em paciente apresentando mais de $2 \mathrm{~mm}$ de gengiva ceratinizada. 
Por se tratar de equipamento eletrônico não designado, e fabricado para suportar altas temperaturas, o controle de infecção cruzada entre os pacientes foi feito por meio de desinfecção química da ponta ativa, realizada pela fricção de compressa de gaze esterilizada embebida em solução de álcool $70 \%$, durante dois minutos.

- Profundidade de sondagem: realizada utilizando-se sonda periodontal milimetrada** Em cada sítio foram realizadas 3 medidas por operador único, previamente calibrado para executar a sondagem com força padronizada de aproximadamente $25 \mathrm{~g}$. Foi considerada como medida final a média das 3 medidas individuais. Como forma de padronização, foram usadas na pesquisa duas sondas periodontais idênticas ${ }^{* *}$, esterilizadas através de calor úmido por vapor sob pressão**. Em todas as áreas avaliadas, as medidas foram realizadas na superfície vestibular dos dentes estudados, nas quais também foram obtidas as medidas de quantidade de gengiva ceratinizada e quantidade de fluido gengival (Figura 3).

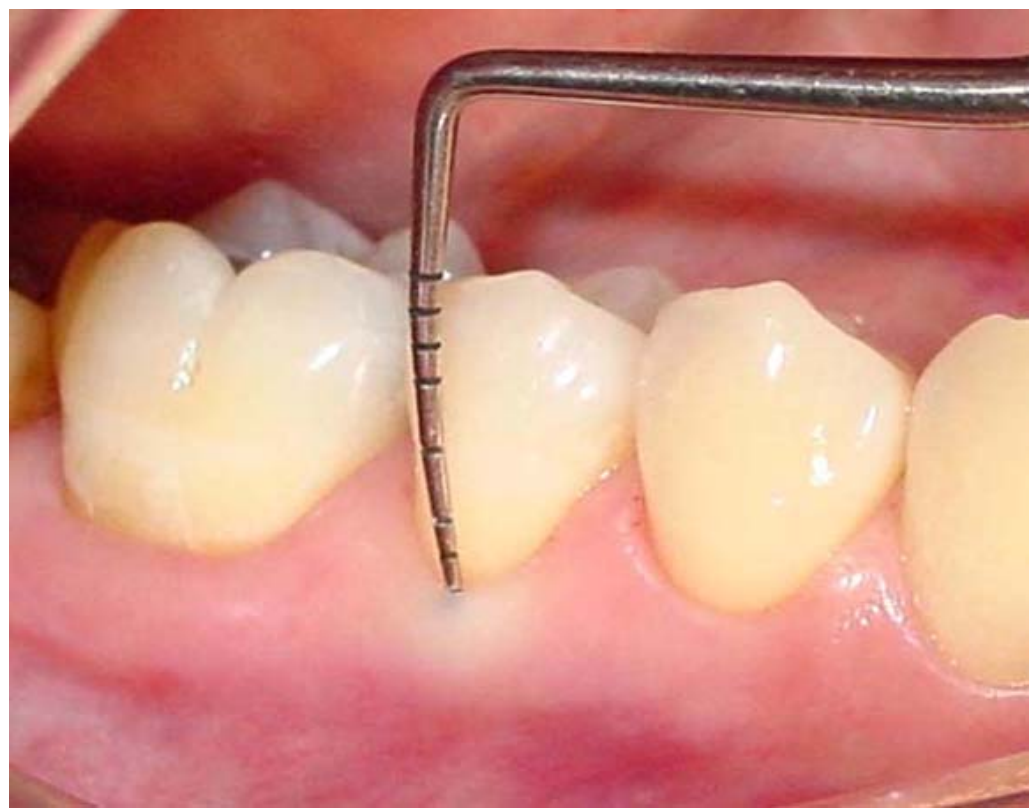

FIGURA 3 - Metodologia de mensuração da profundidade do sulco gengival com sonda periodontal

Sonda posicionada paralelamente ao longo eixo do dente e na região correspondente à medição da quantidade de gengiva ceratinizada.

\footnotetext{
${ }^{* *}$ HU-FRIEDY, USA.

${ }^{\star * *}$ Autoclave Cristófoli.
} 
- Índice de sangramento sulcular: obtido após a realização da medida da profundidade de sondagem clínica com a sonda periodontal ${ }^{* *}$, respeitando os princípios preconizados por MÜHLEMANN; SON ${ }^{51}$, em 1971, que combinam estimativas clínicas de inflamação e sangramento à sondagem, numa escala de $\mathbf{0}$ a $\mathbf{5}$, na qual $\mathbf{0}$ representa aparência saudável e sem sangramento à sondagem; 1 aparência saudável sem alteração de cor e volume, porém com sangramento à sondagem do sulco após até 30 segundos; 2 sangramento à sondagem e mudança de cor da gengiva devido à inflamação e sem presença de aumento de volume; 3 sangramento à sondagem e mudança na cor da gengiva, com ligeira tumefação edematosa; 4 foi subdividido em dois critérios: (1) sangramento à sondagem e alteração na cor, com tumefação óbvia do tecido e (2) sangramento à sondagem e tumefação óbvia; 5 sangramento à sondagem e sangramento espontâneo, mudança na cor e tumefação acentuada do tecido, com ou sem ulceração.

Como foi realizada padronização da amostra previamente à coleta do fluido gengival, e tendo em vista que os dentes selecionados se apresentavam clinicamente saudáveis (sem sinais clínicos de inflamação e sem bolsa periodontal) e que foram submetidos à terapia periodontal, o SBI ficou mais restrito à ausência ou presença de sangramento à sondagem e limitou-se a $\mathbf{0}$ em todos os pacientes no momento da coleta dos dados.

- Quantidade de fluido gengival: obtido por meio da utilização de tiras de filtro de papel absorvente PerioPaper ${ }^{* * *}$. A quantidade de fluido gengival extravasada pelo sulco gengival foi medida antes e após a mastigação de alimento fibroso culinariamente preparado (carne bovina), por 10 minutos. A coleta do fluido gengival foi feita com tiras de papel absorvente, PerioPaper ${ }^{* * *}$, segundo o método proposto por LÖE; HOLM-PEDERSEN ${ }^{42}$, envolvendo inicialmente a coleta extra-sulcular, feita pela justaposição da tira à face vestibular do dente e continuando-se sobre a mucosa até ultrapassar cerca de $2 \mathrm{~mm}$ apicalmente à união mucogengival

${ }^{* *}$ Oralflow, New York, USA. 
(Posições P1a e P1B - Figura 4A). A seguir, outra tira foi posicionada justaposta ao dente, exatamente no nível da margem gengival, porém sem adentrar o sulco gengival (Posição P2 - Figura 4B). Numa terceira medida, a tira de papel foi colocada intrasulcularmente (Posição P3 - Figura 4C), conforme proposto por BRILL; KRASSE ${ }^{15}$ em 1959. As tiras de papel foram mantidas em posição por 1 minuto, em cada grupo, respeitando-se o tempo de aplicação proposto por NAKASHIMA et al. ${ }^{52}$ e SHAPIRO et al. ${ }^{65}$, em função da realização prévia de teste piloto com três pacientes. Todas as medidas obtidas nesta seqüência, de modo a não haver estímulo na produção do fluxo do fluido gengival (Figura 4). 

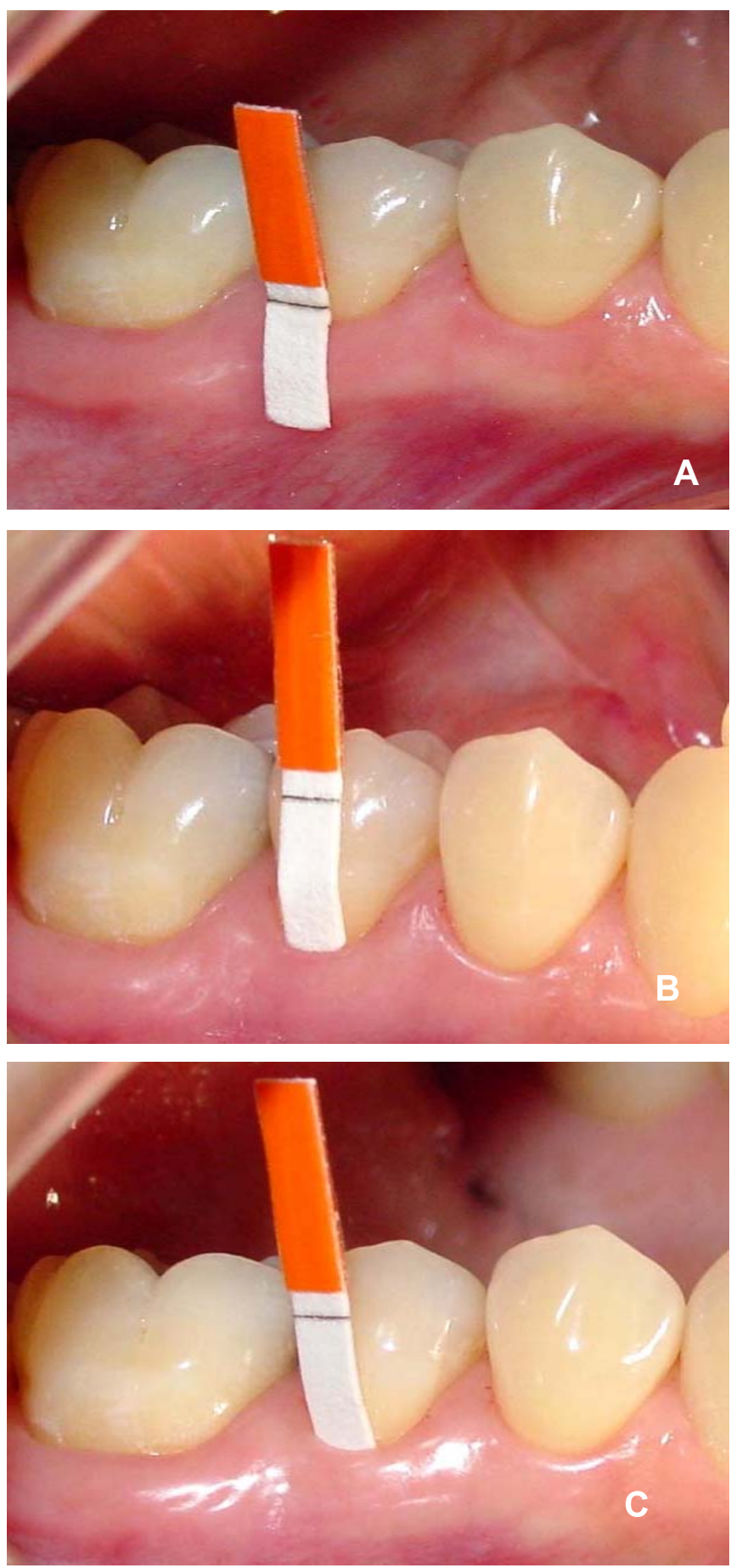

FIGURA 4 - Ilustração da metodologia de mensuração do índice de exsudato

A) posicionamento do PerioPaper sobre o dente, a gengiva e a mucosa alveolar, para obtenção das medidas P1A (mucosa alveolar) e P1B (margem gengival); B) posicionamento do PerioPaper no nível da margem gengival sem adentrar o sulco gengival, para obtenção da medida P2; C) posicionamento do PerioPaper no sulco gengival, para obtenção da medida P3.

$\mathrm{Na}$ posição $\mathrm{P} 1$, foram consideradas duas situações diferentes. $\mathrm{Na}$ posição P1A, a marcação do fluido gengival na tira de papel foi anotada na 
região deste em contato com a mucosa alveolar, aproximadamente $2 \mathrm{~mm}$ apical à linha mucogengival. Na posição P1B a marcação foi anotada na porção média da tira de papel que ficou em contato com a margem gengival.

Em todas as situações, as tiras removidas foram deixadas secar emmeio ambiente com calor, pois a secagem pelo calor é melhor que pelo jato de ar. A secagem elimina a difusão do fluido além do ponto correto de marcação obtido na tira de papel, conforme mencionado por SIEGEL; MANDER; FINE ${ }^{67}$. Posteriormente as tiras foram embebidas em solução alcoólica de ninidrina a $2 \%$, pois esta parece ser mais eficiente do que a solução aquosa neste tipo de marcação ${ }^{67}$. Esta metodologia foi aceita por SUPPIAT; SUPPIPAT ${ }^{73}$, com resultados comparáveis à identificação por meio de aparelhos eletrônicos.

Após a marcação com a solução de ninidrina, as tiras de papel foram secas ao calor, e as áreas coradas foram medidas com paquímetro digital na sua extensão longitudinal (Figura 5). As medidas foram inicialmente obtidas em polegadas e posteriormente foram transformadas em milímetros, para análise estatística.

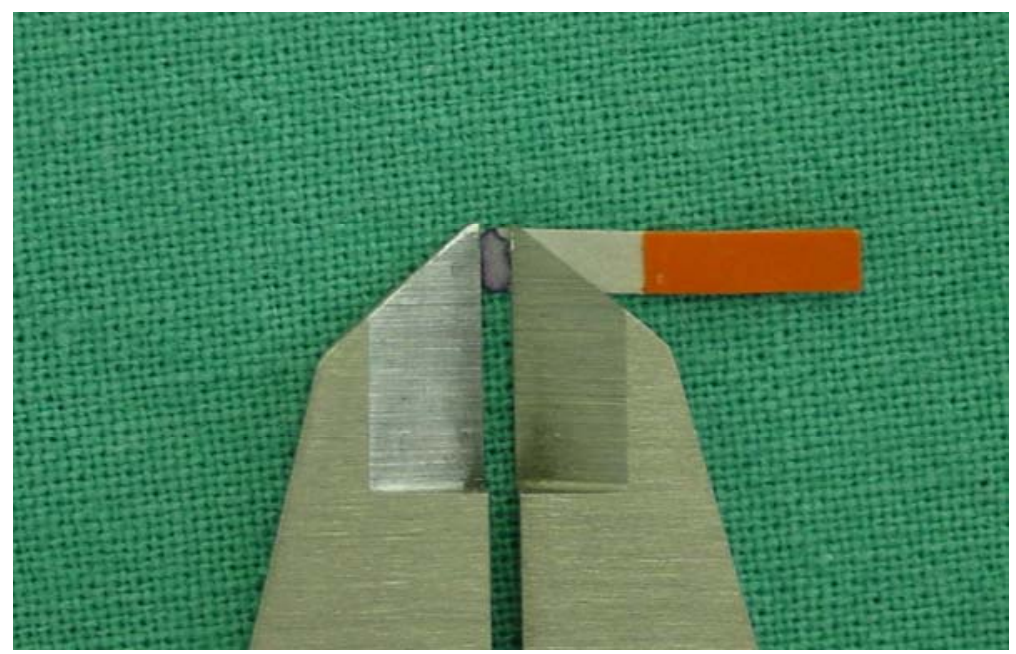

FIGURA 5 - Ilustração da medição linear longitudinal da área embebida pelo fluido gengival na tira de papel

Observe-se que o paquímetro foi disposto de maneira a permitir a marcação da maior distância linear longitudinal corada. 
Para que não houvesse quaisquer interferências nas medidas processadas, os levantamentos dos índices foram feitos na seguinte ordem:

- dia 1: índice de placa, índice de profundidade de sondagem e índice de sangramento sulcular;

- dia 2: quantidade de gengiva ceratinizada;

- dia 3: índice de fluido gengival antes e após a mastigação de alimentos fibrosos (carne bovina).

\subsection{AnÁlise Estatística}

Os dados obtidos foram estatisticamente avaliados segundo os métodos descritivos e através do teste "t" de Student pareado. 
5 RESULtAdOS 


\section{RESULTADOS}

Os resultados provenientes dos achados clínicos e a suas respectivas estatísticas são apresentados sob forma de tabelas, como se segue. 
TABELA 1 - Análise estatística da quantidade de fluido gengival coletada nas regiões que apresentam faixa insuficiente (Grupo $\mathrm{I}<2 \mathrm{~mm}$ ) e faixa adequada (Grupo $A \geq 2 \mathrm{~mm}$ ) de gengiva ceratinizada nas diferentes posições, antes do estímulo mastigatório

\begin{tabular}{l|cccc|cc}
\hline \multirow{2}{*}{ Posição } & \multicolumn{2}{|c}{ Grupo I $(<\mathbf{2 m m})$} & \multicolumn{2}{c}{ Grupo A $(>\mathbf{2 m m})$} & \multirow{2}{*}{$\mathbf{t}$} & P \\
\cline { 2 - 5 } & $\mathbf{X}$ & $\mathbf{d p}$ & $\mathbf{X}$ & $\mathbf{d p}$ & & \\
\hline P1A & 0,331 & 0,382 & 0,825 & 0,79 & $-2,145$ & $0,048^{*}$ \\
\cline { 2 - 5 } P1B & 0,650 & 0,572 & 0,483 & 0,722 & 0,914 & 0,374 \\
P2 & 0,468 & 0,357 & 0,593 & 0,369 & $-1,203$ & 0,225 \\
P3 & 0,962 & 0,393 & 1,056 & 0,453 & $-0,690$ & 0,500 \\
\hline
\end{tabular}

onde:

P1 = posição do papel filtro PerioPaper sobre o dente, e externamente sobre a mucosa;

$\mathrm{P} 1 \mathrm{~A}=$ quantidade de fluido gengival antes do estímulo mastigatório, na posição em que o papel ficou em contato com a mucosa alveolar;

$\mathrm{P} 1 \mathrm{~B}=$ quantidade de fluido gengival antes do estímulo mastigatório, na posição em que a porção média do papel ficou em contato com a margem do sulco gengival;

P2 = quantidade de fluido gengival antes do estímulo mastigatório, para a situação na qual a borda do papel ficou em contato com a margem gengival, sem adentrar o sulco gengival;

P3 = quantidade de fluido gengival antes do estímulo mastigatório, para a situação na qual a borda do papel entrou no sulco gengival até encontrar pequena resistência;

grupo I $=<2 \mathrm{~mm}$ de gengiva ceratinizada .

grupo $A=\geq 2 \mathrm{~mm}$ de gengiva ceratinizada.

* significante se $p \leq 0,05$. 
TABELA 2 - Análise estatística da quantidade de fluido gengival coletada nas regiões que apresentam faixa insuficiente (Grupo I $<2 \mathrm{~mm}$ ) e faixa adequada (Grupo $A \geq 2 \mathrm{~mm}$ ) de gengiva ceratinizada nas diferentes posições, após o estímulo mastigatório

\begin{tabular}{l|cccc|cc}
\hline \multirow{2}{*}{ Posição } & \multicolumn{2}{c}{ Grupo I (<2mm) } & \multicolumn{2}{c}{ Grupo A $(\mathbf{2} \mathbf{m m})$} & \multirow{2}{*}{$\mathbf{t}$} & \multirow{2}{*}{$\mathbf{P}$} \\
\cline { 2 - 5 } & $\mathbf{X}$ & $\mathbf{d p}$ & $\mathbf{X}$ & $\mathbf{d p}$ & & \\
\hline P1A & 0,681 & 0,793 & 0,725 & 0,642 & 0,179 & 0,8598 \\
P1B & 0,550 & 0,579 & 0,893 & 0,699 & 1,733 & 0,1035 \\
P2 & 0,506 & 0,388 & 0,887 & 0,621 & 2,689 & $0,0168^{*}$ \\
\hline P3 & 0,950 & 0,244 & 1,381 & 0,690 & 2,300 & $0,0361^{*}$ \\
\hline
\end{tabular}

onde:

$\mathrm{P} 1 \mathrm{~A}=$ quantidade de fluido gengival após o estímulo mastigatório, na posição em que o papel ficou em contato com a mucosa alveolar;

$\mathrm{P} 1 \mathrm{~B}=$ quantidade de fluido gengival após o estímulo mastigatório, na posição em que a porção média do papel ficou em contato com a margem do sulco gengival;

P2 = quantidade de fluido gengival após o estímulo mastigatório, para a situação em que a borda do papel ficou em contato com a margem gengival, sem adentrar no sulco gengival;

P3 = quantidade de fluido gengival após o estímulo mastigatório, para a situação em que a borda do papel entrou no sulco gengival até encontrar pequena resistência;

grupo I $=<2 \mathrm{~mm}$ de gengiva ceratinizada .

grupo $A=\geq 2 \mathrm{~mm}$ de gengiva ceratinizada.

${ }^{*}$ significante se $p \leq 0,05$.

De forma geral, pôde-se observar diferença estatisticamente significativa $(p<0,05)$ antes do estímulo mastigatório na posição $1 \mathrm{~A}$, maior no lado onde existia quantidade adequada de gengiva ceratinizada. A comparação entre as demais posições não mostrou definição estatisticamente significante $(p>0,05)$ na quantidade do fluxo de fluido gengival nas áreas que apresentam maior $(\geq 2 \mathrm{~mm})$ ou menor $(\leq 2 \mathrm{~mm})$ faixa de gengiva ceratinizada. Após o estímulo mastigatório, aquela diferença deixou de existir $(p>0,05)$, o que indica que a quantidade do fluxo de fluido 
gengival aumentou no grupo que apresentava faixa inadequada de gengiva ceratinizada. Houve, ainda, diferenças estatisticamente significativas entre os grupos após o estímulo mastigatório nas posições 2 e $3(p \leq 0,05)$, o que sugere que o fluxo de fluido gengival também aumentou nas áreas que apresentavam mais de $2 \mathrm{~mm}$ de gengiva ceratinizada.

Nas Tabelas 3 e 4 estão demonstrados os resultados da quantidade do fluxo de fluido gengival nos diferentes grupos (quantidade insuficiente ou adequada de gengiva ceratinizada), antes e depois da mastigação.

TABELA 3 - Análise estatística da quantidade de fluido gengival coletada de áreas com mais de $2 \mathrm{~mm}$ de gengiva ceratinizada (grupo $\mathrm{A}$ ) antes e depois da mastigação, nas diferentes posições

\begin{tabular}{l|cccc|cc}
\hline \multirow{2}{*}{ Posição } & \multicolumn{2}{|c}{ ANTES } & \multicolumn{2}{c}{ DEPOIS } & \multirow{2}{*}{$\mathbf{t}$} & P \\
\cline { 2 - 5 } & $\mathbf{x}$ & $\mathbf{d p}$ & $\mathbf{x}$ & $\mathbf{d p}$ & & \\
\hline P1A & 0,825 & 0,791 & 0,725 & 0,642 & 0,621 & 0,5438 \\
P1B & 0,443 & 0,722 & 0,893 & 0,699 & 2,283 & $0,0373^{*}$ \\
P2 & 0,593 & 0,369 & 0,887 & 0,621 & 1,982 & 0,0660 \\
\hline P3 & 1,056 & 0,453 & 1,381 & 0,690 & 2,160 & $0,0473^{*}$ \\
\hline
\end{tabular}

onde:

$\mathrm{P} 1 \mathrm{~A}=$ quantidade de fluido gengival na posição em que o papel ficou em contato com a mucosa alveolar;

$\mathrm{P} 1 \mathrm{~B}=$ quantidade de fluido gengival na posição em que a porção média do papel ficou em contato com a margem do sulco gengival;

P2 = quantidade de fluido gengival na posição em que a borda do papel ficou em contato com a margem gengival, sem adentrar no sulco gengival;

P3 = quantidade de fluido gengival na posição em que a borda do papel entrou no sulco gengival até encontrar uma pequena resistência;

significante se $p \leq 0,05$. 
TABELA 4 - Análise estatística da quantidade de fluido gengival coletada de áreas com menos de $2 \mathrm{~mm}$ de gengiva ceratinizada (grupo I), antes e depois da mastigação, nas diferentes posições

\begin{tabular}{l|cccccc}
\hline \multirow{2}{*}{ Posição } & \multicolumn{2}{|c}{ ANTES } & \multicolumn{2}{c}{ DEPOIS } & \multirow{2}{*}{ t } & P \\
\cline { 2 - 5 } & $\mathrm{x}$ & $\mathrm{dp}$ & $\mathrm{x}$ & $\mathrm{dp}$ & & \\
\hline P1A & 0,331 & 0,382 & 0,681 & 0,793 & 2,139 & $0,0492^{*}$ \\
P1B & 0,650 & 0,572 & 0,550 & 0,579 & 0,560 & 0,5834 \\
P2 & 0,468 & 0,357 & 0,506 & 0,388 & 0,443 & 0,6638 \\
P3 & 0,962 & 0,393 & 0,950 & 0,244 & 0,104 & 0,9179 \\
\hline
\end{tabular}

onde:

$\mathrm{P} 1 \mathrm{~A}=$ quantidade de fluido gengival na posição em que o papel ficou em contato com a mucosa alveolar;

$\mathrm{P} 1 \mathrm{~B}=$ quantidade de fluido gengival na posição em que a porção média do papel ficou em contato com a margem do sulco gengival;

P2 = quantidade de fluido gengival na posição em que a borda do papel ficou em contato com a margem gengival, sem adentrar no sulco gengival;

P3 = quantidade de fluido gengival na posição em que a borda do papel entrou no sulco gengival até encontrar uma pequena resistência;

significante se $p \leq 0,05$.

A análise global das tabelas permitiu observar que não havia diferenças estatisticamente significantes nas diferentes posições quando a faixa de gengiva ceratinizada era inferior a $2 \mathrm{~mm}$, com exceção da posição $\mathrm{P} 1 \mathrm{~A}$, em que a tira de papel foi posicionada extra-sulcularmente, ultrapassando a linha muco-gengival. No grupo com maior quantidade de gengiva ceratinizada houve diferenças estatisticamente significativas $(p<0,05)$ quando as tiras de papel foram posicionadas em contato com a margem gengival (P1B) e intra-sulcularmente (P3). Embora na posição 2 este achado não fosse observado, houve uma tendência de aumento do fluido gengival após o estímulo mastigatório $(p=0,06)$. 
TABELA 5 - Caracterização clínica dos pacientes por meio dos índices de placa dentobacteriana, sangramento gengival, profundidade de sondagem do sulco gengival, quantidade de gengiva ceratinizada e quantidade de fluido gengival nas áreas com quantidade insuficiente e adequada de gengiva ceratinizada

\begin{tabular}{|c|c|c|c|}
\hline & $\mathrm{N}^{\circ}$ de Amostras & Média & d.p \\
\hline IP & 16 & 0,000 & 0,000 \\
\hline ISG & 16 & 0,000 & 0,000 \\
\hline PS Grupo I $(<2 \mathrm{~mm})$ & 16 & 0,750 & 0,258 \\
\hline PS Grupo A ( $\geq 2 \mathrm{~mm})$ & 16 & 0,875 & 0,223 \\
\hline GC Grupo I (<2mm) & 16 & 0,993 & 0,525 \\
\hline GC Grupo A ( $\geq 2 \mathrm{~mm})$ & 16 & 2,912 & 0,717 \\
\hline FG P1A Grupo I $(<2 \mathrm{~mm})$ & 16 & 0,331 & 0,382 \\
\hline FG P1A Grupo A ( $\geq 2 \mathrm{~mm})$ & 16 & 0,825 & 0,791 \\
\hline FG P1B Grupo I (<2mm) & 16 & 0,650 & 0,572 \\
\hline FG P1B Grupo A ( $\geq 2 \mathrm{~mm})$ & 16 & 0,443 & 0,722 \\
\hline FG P2 Grupo I (<2mm) & 16 & 0,468 & 0,357 \\
\hline FG P2 Grupo A ( $\geq 2 \mathrm{~mm})$ & 16 & 0,593 & 0,369 \\
\hline FG P3 Grupo I (<2mm) & 16 & 0,962 & 0,393 \\
\hline FG P3 Grupo A ( $\geq 2 \mathrm{~mm})$ & 16 & 1,056 & 0,453 \\
\hline
\end{tabular}

onde:

IP = Índice de placa dentobacteriana;

FG $P 1 A=$ quantidade de fluido gengival ISG = Índice de sangramento gengival;

Grupo I = quantidade insuficiente $(<2 \mathrm{~mm})$ de gengiva ceratinizada;

Grupo $A=$ quantidade adequada $(>2 \mathrm{~mm})$ de gengiva ceratinizada;

$\mathrm{PS}=$ profundidade de sondagem do sulco gengival; na posição $\mathrm{P} 1 \mathrm{~A}$;

FG $P 1 B=$ quantidade de fluido gengival na posição $P 1 B$;

FG P2 = quantidade de fluido gengival na posição $P 2$;

FG P3 = quantidade de fluido gengival na posição P3.

$\mathrm{GC}=$ quantidade de gengiva ceratinizada; 


\section{DISCUSSÃO}

As características estruturais e fisiológicas dos tecidos que compõem o periodonto de proteção e sustentação refletem a importância da preservação e da harmonia funcional desses componentes na homeostasia periodontal.

Como se verifica na revisão da literatura, vários trabalhos ${ }^{13,21,36,76,78,79}$ enfocam que em regiões com mínima ou até nenhuma quantidade de gengiva ceratinizada parece possível manter-se clinicamente a saúde periodontal, desde que profissionalmente e pelo indivíduo seja mantida a higiene bucal adequada. Em outras palavras, esses resultados parecem indicar a efetividade do profissional em controlar a placa dentobacteriana, porém não reflete a capacidade homeostática das estruturas periodontais, responsável pela integridade fisiológica do sulco gengival. Nesse mister, ressalta-se a importância do fluido gengival, cuja quantidade e qualidade parece ser fator de relevância na preservação de microbiota subgengival compatível com a saúde periodontal ${ }^{15,16,18,35,44,67}$.

No presente trabalho pôde-se observar, antes da mastigação, que a quantidade de fluido gengival na região sulcular não apresentou variação significante entre as condições estruturais estudadas (Tabela 1), o que pode ser explicado pelo fato de que os pacientes apresentavam condições clínicas de saúde similares, e os índices apresentavam valores baixos, de modo que a variabilidade entre eles foi pequena para o tamanho da amostra. De qualquer forma, esses valores eram esperados, uma vez que os pacientes apresentaram-se em condições clínicas periodontais saudáveis (Tabela 5) e tem sido considerado que, em condições de gengiva estritamente normal, pouco ou nenhum fluido pode ser coletado ${ }^{16,18,35,42,50 .}$ 
Embora isto não esteja concorde com as observações de LANG; $\mathrm{LÖE}^{38}$, estes autores trabalharam com pacientes que apresentavam índice gengival positivo, denotando algum grau de inflamação gengival, enquanto no presente trabalho os pacientes foram mantidos com índice igual ou muito próximo de zero.

Os resultados também diferem daqueles de LÖE; HOLMPEDERSEN ${ }^{42}$, que observaram índice de exsudato zero em áreas mantidas estritamente saudáveis clinicamente, em dentes anteriores.

Portanto, diferenças metodológicas podem ser reputadas como os fatores de variação dos resultados, uma vez que no presente trabalho os espécimes da amostra mantinham seus hábitos rotineiros de vida.

Neste aspecto vale a pena relembrar que a preservação da integridade fisiológica do sulco gengival por diferentes mecanismos, dentre os quais o fluido gengival e elementos celulares de defesa, fazem parte do mecanismo homeostático do periodonto marginal ${ }^{44}$, o que parece ter sido comprovado nos resultados manifestados, pois os pacientes apresentavam gengiva clinicamente saudável.

Na Tabela 1 também se pode ver que a quantidade de fluido na área de mucosa alveolar foi significantemente maior para as áreas de maior quantidade de gengiva ceratinizada do que para as de menor, dados esses aparentemente ainda não mencionados na literatura pesquisada. Veja-se que SIEGEL ${ }^{66}$ se reportou à pobreza de dados na literatura a respeito da permeabilidade da mucosa bucal.

É interessante ressaltar a possibilidade de que a presença de uma faixa determinada de gengiva ceratinizada parece isolar a resposta da mucosa alveolar em relação à margem gengival, talvez proporcionando concentração de fluido naquela região por não haver difusão para o sulco gengival. Em outras palavras, quanto maior a distância do fundo do sulco 
gengival à união mucogengival, menor a influência de fatores do sulco gengival no comportamento da mucosa alveolar.

Esses resultados ilustram o fato de que a mucosa alveolar apresenta grau de permeabilidade maior que a gengiva ceratinizada, o que pode ser fator de relevância na resposta homeostática periodontal ${ }^{8,48,61}$.

Cite-se o fato de que a permeabilidade da mucosa funciona nos dois sentidos, ou seja, impedindo ou permitindo a passagem de determinadas substâncias do meio interno para o externo e vice-versa ${ }^{44,66}$.

Todos os resultados obtidos ilustraram a presença de algum grau de fluido gengival na área de mucosa alveolar, o mesmo não ocorrendo na gengiva ceratinizada, o que indica a maior permeabilidade da mucosa alveolar.

Essa é provavelmente a razão pela qual têm sido usadas substâncias evidenciadoras para marcar a mucosa alveolar, em trabalhos que analisam o comportamento da gengiva ceratinizada ${ }^{5,18,30,61}$.

PASSANEZI et al. ${ }^{61}$ ressaltaram a importância da permeabilidade da mucosa alveolar como fator de reconhecimento de agentes potencialmente agressivos, dessa maneira permitindo ao organismo o preparo da defesa da área do sulco gengival até mesmo antes da formação de placa dentobacteriana, inclusive pela maturação de um sistema imunocompetente. Para os autores isso explicaria porque pessoas saudáveis, que nunca tiveram doença periodontal infecciosa, apresentam anticorpos específicos antiagentes da placa, conforme mencionado por BRANDTZAEG (apud PASSANEZl et al. ${ }^{61}$ ).

Também se deve ressaltar a importância dessa permeabilidade como mecanismo de defesa do meio externo por criar fluxo do fluido tecidual de dentro para fora, como se pode atestar pela impregnação do papel-filtro na posição P1A (Tabelas 1 e 2). 
Esse aumento do fluido tecidual na área da mucosa alveolar provavelmente se relaciona com a maior mobilidade desse tecido, necessária para atender às necessidades metabólicas das demandas funcionais (PASSANEZI et al. ${ }^{61}$ ).

$\mathrm{Na}$ Tabela 2, pela qual foi avaliada a quantidade de fluido gengival após a mastigação nas mesmas áreas analisadas na Tabela 1, verificou-se aumento significativo na quantidade de fluido na margem gengival $e$ intrasulcular das regiões de faixa adequada, comparadas às faixas inadequadas de gengiva ceratinizada. Tal comportamento poderia enfatizar a saída de fluido gengival como efeito de lavagem e fazendo parte do mecanismo de defesa local da gengiva, refletindo a capacidade homeostática das estruturas periodontais frente a estímulos mastigatórios, conforme sugerido por BRILL ${ }^{14}$, em 1959. O fato de se obter em valores menores da quantidade de fluido gengival nas áreas com quantidade insuficiente de gengiva ceratinizada pode ser explicado por possível dispersão (diluição) do fluido tecidual, de forma que uma quantidade menor teria acesso à área sulcular, o que reflete condições fisiológicas com menor potencial defensivo destas estruturas. Tenha-se presente que o fluido gengival é considerado um dos mecanismos de defesa do sulco gengival $^{9,11,14,15,16,18,25,35,42,45,56,57,61,64}$.

Assim, embora vários autores ${ }^{13,21,36,76,78,79}$ considerem ser possível manter saúde periodontal em áreas com quantidade mínima ou ausente de gengiva ceratinizada, os resultados obtidos no presente trabalho sugerem que, apesar dos aspectos clínicos normais, estas estruturas teriam comportamento homeostático mais crítico para manter a integridade fisiológica do sulco gengival, desta maneira justificando-se a necessidade mencionada por aqueles autores de se ter que manter a higiene bucal do paciente sob controle criterioso e rígido do profissional.

A importância de uma faixa adequada de gengiva ceratinizada no comportamento fisiológico periodontal também foi ressaltada por ERICSSON; LINDHE ${ }^{24}$, em 1984, que verificaram a ocorrência de recessão 
gengival em áreas com gengiva ceratinizada inadequada, nas quais foram cimentadas bandas ortodônticas subgengivalmente, simulando restaurações intrasulculares a $1,0 \mathrm{~mm}$ de profundidade. Esses resultados parecem demonstrar melhor comportamento homeostático das áreas contendo quantidade adequada de gengiva ceratinizada. Como esses aspectos foram correlacionados à formação de placa dentobacteriana subgengival, talvez parte do mecanismo defensivo pudesse ser atribuída ao efeito de lavagem sugerido por WAERHAUG; STEEN, em 1952 (apud CIMASONI ${ }^{18}$ ) e BRILL ${ }^{14}$, em 1959.

A presença de células inflamatórias em áreas clinicamente saudáveis poderia caracterizar o mecanismo homeostático, como defendido por MACPHEE; COWLEY ${ }^{44}$. Para KINANE; LINDHE ${ }^{35}$ a gengiva clinicamente saudável pode resistir a agressões bacterianas sem progredir para doença provavelmente devido a vários fatores defensivos, dentre os quais o fluxo do fluido gengival, capaz de remover microorganismos e seus produtos.

Ao avaliar a quantidade de fluido gengival antes e após a mastigação, coletado em áreas com quantidade suficiente de gengiva ceratinizada (Tabela 3), foram verificadas diferenças estatisticamente significativas nas áreas da margem gengival (P1B) e intrasulcular (P3) e muito próximas de significativa na área onde a borda do papel ficou em contato com margem gengival (P2).

Esses resultados ilustram o aumento na quantidade do fluido gengival que se processa durante as atividades funcionais do órgão mastigatório, caracterizando-se esse aumento de maneira praticamente homogênea nas áreas diretamente associadas ao fluido gengival. Como os valores da quantidade do fluido gengival se apresentaram muito próximos nas posições P1B e P2, e considerando-se que esses valores refletem a quantidade do fluido extravasado pelo sulco gengival, $O$ fato de haver significância estatística no comportamento do fluido para P1B, e não para $\mathrm{P} 2$, não causou preocupação por refletir provavelmente a variação metodológica na colheita do fluido, uma vez que na posição P1B o papel PerioPaper ficou aposto à 
margem gengival e ao dente, enquanto na P2 somente a extremidade do papel foi posta em contato com a margem gengival. Dessa forma, o aumento produzido nada mais reflete do que o próprio aumento da quantidade do fluido gengival na posição P3 (intrasulcular).

Tal resultado é sugestivo de que a função mastigatória é fator estimulante do mecanismo homeostático do periodonto marginal, quando se considera o papel protetor do fluido gengival ${ }^{14,15,16,18,35}$.

Na posição P1A não houve diferença estatisticamente significante na quantidade de fluido, o que indica que não há alterações comportamentais, nesse aspecto, na área da mucosa alveolar, quando o indivíduo apresenta faixa adequada de gengiva ceratinizada.

Ressalte-se, ainda, que no presente trabalho procurou-se eliminar variáveis "artificiais", como experimentos em animais não humanos e mastigação de "simulantes de alimentos", visando reproduzir as condições usuais da vida rotineira pela colheita dos dados antes e após a mastigação de alimentos naturais fibrosos e condimentados (carne bovina temperada).

$\mathrm{Na}$ Tabela 4, em condições de quantidade insuficiente de gengiva ceratinizada, encontrou-se diferença estatisticamente significativa após o estímulo mastigatório apenas nas áreas de mucosa alveolar (P1A), o que parece justificar mais uma vez a possibilidade de o fluido tecidual ter-se difundido pelos tecidos em vez de se concentrar na região do sulco gengival.

Tendo-se presente os resultados da Tabela 3 e considerando que o fluido gengival tem função defensiva ${ }^{9,14,15,16,18,25,37,44,46,61,66,67}$, parece aceitável assumir-se que essa função é mais bem elaborada nas áreas com quantidade adequada de gengiva ceratinizada, ou, pelo menos, que a gengiva ceratinizada influencia o comportamento homeostático do periodonto marginal em resposta aos estímulos funcionais. Talvez não fosse demais assumir, pois, que essa ação protetora também se manifestaria em relação a estímulos outros, agressivos do sulco gengival. 
Veja-se que BOWERS ${ }^{13}$, em 1963, considerou possível manter saúde periodontal com pouca ou nenhuma gengiva ceratinizada na ausência de placa dentobacteriana, porém com maior risco de apresentar inflamação, ao menor descuido da higiene bucal.

TREY; BERNIMOULIN ${ }^{76}$, em 1980, ao comparar dentes com quantidade insuficiente de gengiva ceratinizada que receberam enxerto gengival livre, com dentes controle que apresentavam condições clínicas similares e não receberam enxerto, encontrou diferenças significativas para menor no índice de placa dentobacteriana da região vestibular média no lado teste nas primeiras 7 semanas e no índice de placas vestíbulo-proximais nos lados teste e controle em todo o período experimental (14 semanas). Esses resultados parecem denotar que, após semanas de controle, o paciente assimila a motivação para manter a boca limpa, porém o curto espaço de tempo de acompanhamento pode ter sido fator determinante para a falta de alterações significativas nos parâmetros clínicos avaliados.

Também WENNSTROM $^{78}$, em 1986, em estudo longitudinal em pacientes com bom controle de placa dentobacteriana, propôs que a falta de gengiva inserida adequada não resultou em aumento da incidência de recessão.

Tais trabalhos parecem refletir o fato de que o controle profissional é eficiente na preservação da higiene bucal, ilustrando o risco de que alterações possam ser produzidas em áreas com pouca gengiva ceratinizada.

Esses resultados parecem concordar com o deste trabalho, pois, apesar das condições inadequadas da quantidade de gengiva ceratinizada, os índices de placa e de sangramento foram nulos (Tabela 5).

Todavia, a maioria dos trabalhos revistos na presente literatura ${ }^{13,21,36,76,78,79,80,81}$, que considerou ser possível manter saúde periodontal com pouca ou até nenhuma gengiva ceratinizada, foi realizada 
em animais ou em condições criadas "artificialmente" para se conseguir excelentes condições de higiene bucal, o que poderia justificar seus objetivos. Contudo, quando se avaliam trabalhos $7,10,20,49,55,54,82,83,84$ que analisam as condições propostas de manutenção, tanto em clínicas privadas como públicas, a porcentagem de "compliance" é muito baixa, raramente chegando de faixa a $40-50 \%$, o que significa que a preservação da higiene bucal é crítica. Portanto, as condições experimentais não refletem as reais condições de comportamento necessárias para se analisar o requerimento ou não da presença de quantidade mínima de gengiva ceratinizada para manutenção da saúde periodontal.

Neste mister, LANG; LÖE ${ }^{38}$ mostraram alterações significativas no índice de fluido gengival em indivíduos com boa higiene bucal, porém com faixas maiores e menores que $2 \mathrm{~mm}$ de gengiva ceratinizada.

A importância da gengiva ceratinizada ficou bem clara no trabalho de KENNEDY et al. ${ }^{34}$ de 1985 , no qual os autores concluíram que é possível manter a saúde periodontal e o nível de inserção clínica pelo controle profissional/paciente da higiene bucal, a despeito da ausência de gengiva inserida; porém, quando a higiene foi mantida apenas pelos pacientes, áreas com quantidade insuficiente de gengiva ceratinizada apresentaram inflamação gengival associada a recessão adicional. Embora não tenham sido explorados pelos autores, esses resultados são bem indicativos de que a presença de gengiva ceratinizada é mais compatível com o comportamento homeostático do periodonto marginal do que as condições obtidas com quantidades inadequadas.

Em outras palavras, a presença de gengiva ceratinizada na área marginal seria mais compatível com o comportamento homeostático do periodonto marginal do que com a de mucosa alveolar, conforme proposto por PASSANEZI et al. ${ }^{61}$. Não se deixe de lado a menção de MENDONÇA ${ }^{48}$ de que a presença de gengiva inserida adequada é importante no estabelecimento das distâncias biológicas, as quais, por sua vez, coordenam as funções fisiológicas ${ }^{8,48,61}$. 
Outro fator de importância quanto á presença do fluido em gengiva clinicamente saudável, relatado por alguns investigadores ${ }^{2,4,18}$, é que o fluxo do fluido gengival aumenta vários dias antes de uma inflamação clinicamente detectável. Assim, a produção do fluido gengival pode ser inicialmente gerada por um gradiente osmótico, influenciando a passagem de fluido e leucócitos polimorfonucleares no sulco, pelo menos no início.

Todavia, essa probabilidade de influência de fatores inflamatórios não se manifestou no presente estudo, uma vez que as mensurações foram feitas em lapso de tempo extremamente curto, provavelmente não tendo influência decisiva na quantidade de fluido extravasado. Considere-se que os pacientes apresentavam-se clinicamente saudáveis e com boa higiene bucal.

Segundo o modelo matemático proposto por PASHLEY ${ }^{59}$, em 1976, o fluxo do fluido gengival final dependerá não somente da diferença entre a filtração capilar e a remoção linfática, mas também do coeficiente de filtração dos epitélios sulcular e juncional, especialmente da diferença entre a pressão osmótica do fluido intersticial e aquela do fluido sulcular. Tal modelo suporta a hipótese de $\mathrm{ALFANO}^{2}$, de 1974, segundo a qual o fluxo aumenta quando a pressão osmótica do compartimento sulcular excede aquela do fluido intersticial, devido à presença de subprodutos bacterianos. O modelo matemático indica que há uma tendência de aumento na produção do fluido gengival final. Quando inflamação estiver presente, pressões osmóticas serão idênticas nos compartimentos sulculares e tissulares, devido a concentrações idênticas de proteínas no fluido gengival e no soro. A igualdade de ambas as pressões osmóticas cancelaria, assim, sua importância na produção de fluido, cuja exsudação dependerá muito mais da pressão capilar do que de gradientes osmóticos.

Como esses eventos relacionam-se a áreas de permeabilidade tecidual, procurou-se avaliar a saída de fluido também na zona da mucosa alveolar. 
O emprego de tiras de papel absorvente PerioPaper é, de longe, o mais utilizado, até mesmo para investigações quantitativas da composição do fluido gengival. A quantidade e a composição do fluido gengival têm sido investigadas em situações clínicas sabidas que afetam as estruturas periodontais.

A análise conjuntiva das Tabelas 1, 2, 3 e 4 permite considerar que a variação na quantidade de gengiva ceratinizada influenciou não só a quantidade do fluxo de fluido gengival via sulco gengival como também a saída de fluido na região da mucosa alveolar.

É interessante que nesta faixa de mucosa alveolar a quantidade de fluido aumentou significantemente em regiões de gengiva ceratinizada inadequada, enquanto a quantidade de fluido aumentou significantemente nas áreas relacionadas ao sulco gengival quando havia quantidade adequada de gengiva ceratinizada.

Esses resultados parecem indicar a possibilidade de difusão do fluido tecidual entre a área do sulco gengival e a da mucosa alveolar em função da diminuição da faixa de gengiva ceratinizada.

Além disso, a variação dos valores da transudação do fluido gengival na margem gengival seguramente não foi influenciada por irritação pela colocação da tira de PerioPaper no sulco gengival, porque a determinação da quantidade de fluido gengival intrasucular foi feita posteriormente àquela na margem gengival, respeitando-se a proposta de LÖE; HOLM-PEDERESN ${ }^{42}$.

De modo geral, portanto, os resultados mostram que 0 ato da mastigação produz alteração na quantidade de fluido gengival extravasado via sulco gengival, com variabilidade relacionada à quantidade de gengiva ceratinizada existente. 
Há que se considerar o fato de que o fluxo do fluido gengival evidentemente está associado ao aumento da transudação dos vasos sangüíneos e, portanto, aos mecanismos que regulam esse fluxo ${ }^{2,18,59}$.

Nesse mister, pelo menos um dos mecanismos propostos parece estar relacionado à participação das fibras oxitalânicas, descritas por FULLMER; LILLIE (apud TERRANOVA; GOLDMAN; LISTGARTEN ${ }^{75}$ ) e FULLMER $^{27}$. Nos trabalhos de SIMS; JOHNSON ${ }^{33}$, PYLYPAS; GOIRIS ${ }^{29}$ e PASSANEZI; SANT'ANA ${ }^{60}$, em função da localização das fibras oxitalânicas inseridas no cemento e na parede dos vasos sangüíneos, considerou-se a possibilidade de que o movimento do dente transmitiria o estímulo para o vaso sangüíneo, dando, assim, a informação necessária para se controlar o fluxo sangüíneo proporcionalmente à demanda metabólica gerada, de modo a aumentar a transudação de plasma para os tecidos.

Não se pode deixar de lado que tais correlações foram elaboradas para a área limitada ao ligamento periodontal, sendo sugestivo aceitar que é pouco provável haver influência decisiva desse mecanismo na quantidade de fluido gengival.

Entretanto, parece viável considerar-se que a mobilidade dental leva consigo a mobilização da gengiva, além do excursionamento do bolo alimentar e da demanda funcional da mucosa alveolar, abrindo-se a perspectiva de que pudesse haver a participação de fibras oxitalânicas também na área gengival. Assim, há que se direcionar estudos para identificação dessas fibras no ambiente do periodonto de proteção, para melhor elucidação da atividade fisiológica funcional do sistema circulatório.

Tratando-se de pacientes clinicamente saudáveis, no momento parece razoável inferir-se que essas variações comportamentais estejam relacionadas mais diretamente ao processo homeostático do periodonto marginal, com a finalidade de preservar a integridade fisiológica do sulco gengival, tendo-se presente 0 papel protetor do fluido gengival $4,5,8,9,14,15,16,17,18,25,28,35,38,42,46,59,61,64,67,71$. 
7 CONCLUSÕES 


\section{CONCLUSÕES}

Os resultados obtidos neste estudo, de acordo com a metodologia empregada, permitiram concluir que a maior quantidade de gengiva ceratinizada resulta em comportamento homeostático do periodonto marginal, visto que:

- $\quad$ O ato da mastigação influencia a quantidade de fluido tecidual extravasado marginalmente como fluido gengival;

- A quantidade de gengiva ceratinizada interfere no processo de extravasamento do fluido gengival de modo que influencia a defesa natural do sulco gengival;

- Ocorre aumento fisiológico do fluxo de fluido gengival em resposta à função nas áreas saudáveis com mais de $2 \mathrm{~mm}$ de gengiva ceratinizada, provavelmente representando um mecanismo de defesa primário do sulco gengival;

- Nas áreas onde a faixa de gengiva ceratinizada presente é inferior a $2 \mathrm{~mm}$, não há alteração na taxa de extravasamento do fluido pelo sulco gengival, porém aumenta a saída de fluido tecidual pela mucosa alveolar por difusão com provável diminuição na defesa do sulco gengival; 
REFERÊNCIAS 


\section{REFERÊNCIAS}

1. AIMANO, A.; AIMANO, J. The width of attached gingiva on supraerupted teeth. J. Periodont. Res., v.13, p.194-8, 1978.

2. ALFANO, M. C. The origin of gingival fluid. J. Theory Biol., v.47, n.1, p.127-36, Set. 1974.

3. ALFANO, M. C.; DRUMMOND, J. F.; MILLER, S. A. Localization of rate-limiting barrier to penetration of endotoxin through nonkeratinized oral mucosa in vitro. J. dent. Res., v.54, n.6, p.1143-8, 1975.

4. AlFANO, M. C. et al. Passively generated increase in gingival crevicular fluid flow human gingiva. J. dent. Res., v.55, n.6, p.1132, 1976.

5. ATTSTRÖM, R.; EGELBERG, J. Emigration of blood neutrophils and monocytes into gingival crevices. J. Periodont. Res., v.5, p.48-55, 1970.

6. ATTSTRÖM, R.; BEER, M. G.; SCHROEDER, H. E. Clinical and histologic characteristics of normal gingiva in dogs. J. Periodont. Res., v.10, p.115-27, 1975.

7. BAKDASH, B. Oral hygiene and compliance as risk factors in periodontitis. J. Periodont. Res., v.65, n.5, p.539-43, May 1994. 
8. BARROSO, E. C. Correlação clínica das dimensões de enxerto gingival autógeno livre com a reconstrução dos parâmetros de homeostasia do periodonto marginal. Bauru, 2001. 119p. Tese (Doutorado) - Faculdade de Odontologia de Bauru, Universidade de São Paulo.

9. BEARDMORE, H. D. Tonus of the marginal gingival. J. dent. Res., v.40, p.706, 1961.

10. BERNDSEN, M.; EIJKMAN, M. A. J.; HOOGSTRATEN, J. Compliance perceived by dutch periodontists and hygienists. J. clin. Periodont., v.20, p.668-72, 1993.

11. BICKEL, M.; CIMASONI, G.; ANDERSEN, E. Flow and albumin content of early (pre-inflammatory) gingival crevicular fluid from human subjects. Arch. oral Biol., v.3, n.8, p.599-602, 1985.

12. BLIEDEN, T. M. Tooth-related issue. J. Periodont. Res., v.4, n.1, p.91-110, 1999.

13. BOWERS, G. M. A study of the width of attached gingiva. J. Periodont. Res., v.34, p.201-8, 1963.

14. BRILL, N. Effect of chewing on flow of tissue fluid into human gingival pockets. Acta odontol. Scand, v.17, p.277-84, 1959.

15. BRILL, N.; KRASSE, B. Effect of mechanical stimulation on flow of tissue fluid through gingival pocket epithelium. Acta odontol.Scand, v.17, p.115-30, 1959. 
16. CARRANZA, F. A.; BULKACK, J. Mecanismos de defesa da gengiva. In: CARRANZA, F. A.; NEWMAN JR, M. G. Periodontia Clínica, 8.ed. Rio de Janeiro, Guanabara-Koogan, 1997. Cap.7, p.108-15.

17. CARRANZA, F. A.; TAKEI, H. H. Preparo do periodonto para a dentística restauradora. In: CARRANZA, F. A.; NEWMAN JR, M. G. Periodontia Clínica, 8.ed. Rio de Janeiro, Guanabara-Koogan, 1997. Cap.66, p.769-75.

18. CIMASONI, G. Crevicular fluid updated. In: MONOGRAPHS in oral science. London, Karger, 1983. v.12.

19. DANESHMAND, H.; WADE, A. B. Correlation between gingival fluid measurements and macroscopic and microscopic characteristics of gingival tissue. J. Periodont. Res., v.11, p.35-46, 1976.

20. DEMETRIOU, N.; TSAMI-PANDI, A.; PARASHIS, A. Compliance with supportive periodontal treatment in private periodontal practice. A 14-year retrospective study. J. Periodont. Res., v.66, n.2, p.145-9, Feb. 1995.

21. DORFMAN, H. S.; KENNEDY, J. E.; BIRD, W. Longitudinal evatuation of free autogenous gingival grafts. J. clin. Periodont., v.7, p.31624, 1980.

22. EGELBERG, J. Permeability of the dento-gingival blood vessels. J. Periodont. Res., v.1, p.297-302, 1966.

23. EGELBERG, J.; ATTSTRÖM, R. Comparison between orifice and intracrevicular methods of sampling gingival fluid. J. Periodont. Res., v.8, p.384-8, 1973. 
24. ERICSSON, I.; LINDHE, J. Recession in sites with inadequate width of the keratinized gingiva. J. clin. Periodont., v.11, p.95-103, 1984.

25. FABBRO, M. D. et al. Fluid dynamics of gingival tissues in transition from physiological condition to inflammation. J. Periodont. v.72, n.1, p.65-73, jan, 2001.

26. FINE, D. H.; STUCHELL, R. Correlation of levels of inflamation and inward particle penetration in human gingiva. J. dent. Res., v.56, n.6, p.695, june, 1977.

27. FULLMER, H. M. Observations on the developmente of oxytalan fibers in the periodontium of man. J. dent. Res., p.510-9, May-June, 1959.

28. FULLMER, H. M.; SHEETZ, J. H.; NARKATES, A. J. Oxytalan connective tissue fibers; A review. J. oral Path., v.3, p.291-316, Dec. 1974.

29. GOIRIS, F. A. J. Oclusão e periodontia: mecanismo de transmissão e neutralização de forças oclusais. In: GOIRIS, F. A. J. Conceitos e discussões fundamentais. 2.ed. São Paulo, Ed. Santos, 1999. p.107-29.

30. GUGLIELMONI, P. et al. Intra-and inter-examiner reproducibility in keratinized tissue width assessment with 3 methods of mucogingival junction determination. J. Periodont. Res., v.72, n.2, p.134-9, 2001.

31. HASSEL, T. M. Periodontal tissues structure and function. Periodontology 2000, v.3, p.9-38, 1993. 
32. ITOIZ, M. E.; CARRANZA JR, F. A. A gengiva. In: CARRANZA, N. Periodontia clínica. 8.ed. Rio de Janeiro, Guanabara Koogan, 1997. p.12-30.

33. JOHNSON, R. B.; PYLYPAS, S. P. A re-evaluation of the distribution of the elastic meshwork within the periodontal ligament of the mouse. J. Periodont. Res., v.27, n.4,(pt1) p.239-49, July 1992.

34. KENNEDY, J. E. et al. A longitudinal evaluation of varying widths of attached gingiva. J. clin. Periodont., v.12; n.8, p.667-75, 1985.

35. KINANE, D. F.; LINDHE, J. Patogênese da Periodontite. In: LINDHE, J.; KARRING, T.; LANG, N. P. Periodontia clínica e implantodontia oral. 3.ed. Rio de Janeiro, Guanabara Koogan, 1999. p.127-50.

36. $\mathrm{KISCH}, \quad$ J. B.; EGELBERG, J. Longitudinal observation of "unattached", mobile gingival areas. J. clin. Periodont., v.13, p.131-4, 1986.

37. LAMSTER, I. B. The host response in gingival crevicular fluid: potential applocations in periodontitis clinical trials. J. Periodont. Res., Supplement, p.1117-23, 1992.

38. LANG, N. P.; LÖE, H. The relationship between the width os keratinized gingiva and gingival health. J. Periodont. Res., v.43, n.10, p.623-7, 1972.

39. LINDHE, J.; KARRING, T. Anatomia do periodonto. In: LINDHE, J.; KARRING, T.; LANG, N. P. Periodontia clínica e implantodontia oral. 3.ed. Rio de Janeiro, Guanabara Koogan, 1999. p.3-42. 
40. LINDHE, J.; NYMAN, S. Alterations of the position of the marginal soft tissue following periodontal surgery. J. clin. Periodont., v.7, p.525-30, 1980.

41. LINDHE, J.; NYMAN, S.; ERICSSON, I. Trauma de oclusão: tratado de periodontia clínica e implantologia oral. 3.ed. Rio de Janeiro, Guanabara Koogan, 1997. p.193-205.

42. LÖE, H.; HOLM-PEDERSEN, P. Absence and presence of fluid from normal and inflamed gingivae. J. Periodont. Res., v.3, n.4, p.171-7, 1965.

43. LÖE, H.; LISTGARTEN, M. A.; TERRANOVA, V. P. A gengiva. In: GENCO, R. J.; COHEN, D. W.; GOLDMAN, H. M. Periodontia contemporânea. São Paulo, Ed. Santos, 1996. p.3-32.

44. MACPHEE, T.; COWLEY, G. The environment of the tooth. In: Essentials of periodontology and periodontics. Oxford London Edinburgh Melbourne, Blackwell Scientific Publications, 1995. p.17-27.

45. MARANGONI, G.; DOTTO, C. A.; GROMATZKY, A.; GRISI, M. F. de M. A utilização de testes de diagnóstico em pacientes com periodontite em progressão lenta. Revista Periodontia, v.6, n.1, p.24-7, 1997.

46. MAYNARD JR, J. G.; WILSON, R. D. K. Physiologic dimensions of the periodontium significant to restorative dentist. J. Periodont. Res., v.50, n.4, p.170-3, 1979. 
47. MAYNARD JR., G. Mucogingival considerations for the adolescent patient. In: NEVINS, M.; MELLONIG, J. T. Periodontal therapy: clinical approaches and evidence of success. Chicago, Quintessence, 1999. Cap. 19. v.1.

48. MENDONÇA, J. A. G. Avaliação e análise das distâncias biológicas do periodonto mediante nova metodologia. Bauru, 2001. 202p. Tese (Doutorado) - Faculdade de Odontologia de Bauru, Universidade de São Paulo.

49. MENDOZA, A. R.; NEWCOMB, G. M.; NIXON, K. C. Compliance with periodontal therapy. J. Periodont. Res., v.62, n.12, p.731-6, Dec. 1991.

50. MIYASATO, M.; CRIGGER, M.; EGELBERG, J. Gingival condition in areas of minimal and appreciable width of keratinized gingiva. J. clin. Periodont., v.4, p.200-9, 1977.

51. MÜHLEMANN, H. R.; SON, S. Gingival sulcus bleeding: a leading symptom in initial gingivitis. Helv. Odont. Acta, v.15, p.107-13, Oct. 1971.

52. NAKASHIMA, K. et al. Osteocalcin prostaglandin $E_{2}$ and alkaline phosphatase in gingival crevicular fluid: their relations to periodontal status. J. clin. Periodont., v.21, p.327-33, 1994.

53. NOVAES, A. B. et al. The development of the periodontal cleft. A clinical and histopathologic study J. Periodontol., v.46, n.12, p.701-9, Dec, 1975. 
54. NOVAES JR., A. B.; NOVAES, A. B. Compliance with supportive periodontal therapy. Part 1. Risk of non-complicance in the first 5year period. J. Periodont. Res., v.70, n.6, p.679-82, June 1999.

55. NOVAES JR., A. B.; NOVAES, A. B. Compliance with supportive periodontal therapy. Part II. Risk of non-complicance in the first 10-year period. Braz. Dent. J., v.12, n.1, p.47-50, 2001.

56. OLIVER, R. C.; HOLM-PEDERSEN, P.; LÖE, H. The correlation between clinical soring, exudate measurements and microscopic avaluation of inflammation in the gingiva. J. Periodont. Res., v.40, p.201-9, 1969.

57. ORBAN, J. E.; STALLARD, R. E. Gingival crevicular fluid: A reliable recidtor of gingival health?. J. Periodont. Res., v.40, p.231-5, 1969.

58. PAGE, R.C.; SHROEDER, H. E. Pathogenesis of inflammatory periodontal disease: a summary of current work. Laboratory Investigation, v.33, p.235-49, 1976.

59. PASHLEY, D. H. A mechanistic analysis of gingival fluid production. J. Periodont. Res., 11, n.2, p.121-134, Apr. 1976.

60. PASSANEZI, E.; SANT'ANA, A. C. P. Papel da oclusão traumatogênica em periodontia e Implantologia. In: TUNES, U. R.; RAPP, G. (eds.). Atualização em Periodontia e Implantodontia. São Paulo, Artes Médicas, 1999. Cap. 14, p.253-93. 
61. PASSANEZI, E. et al. Planejamento periodontal tendo em vista tratamentos estético e protético. In: GONÇALVES, E. A. N.; FELLER, C. Atualização na clínica odontológica. São Paulo, Artes Médicas, 1998. Cap. 20, p.481-540.

62. POUSEN, S.; HOLM-PEDERSEN, P.; KELSTRUP J. Comparison of different measurements of development of plaque and gingivitis in man. J. dent. Res., v. 87, p.178-83, 1979.

63. RAMFJORD, S. P.; ASH JR., M. M. Estruturas periodontais. In: - Periodontologia e periodontia: teoria e prática moderna. São Paulo, Ed. Santos, c1991. Cap.1, p.1-3.

64. SCHLUGER, S. et al. Periodontal diseases. 2.ed. Philadelphia, Lea \& Dental Medicina: Penodontology, 1990. Cap.26-27, p.560-4.

65. SHAPIRO, L.; GOLDMAN, H.; BLOOM, A. Sucular exudate flow in gingival inflammation. J. Periodont. Res., v.50, p.301-4, 1979.

66. SIEGEL, I. A. Permeability of the oral mucosa. In: MEYER, J.; SQUIER, C. A.; GERSON, S. J., ed. The structure and function of oral mucosa. Oxford, Pergamon Press, 1984. p.95-108.

67. SIEGEL, K. L.; MANDEL, I. D.; FINE, D. The measurement of gingival fluid. J. Periodont. Res., v.43, n. 11, 1972.

68. SILNESS, J.; LÖE, H. Periodontal disease in pregnancy. Acta odont. scand., v.22, p.121-35, 1964. 
69. SIMS, M. R. Oxytalan-vascular relationships observed in histologic examination of the periodontal ligaments of man and mouse. Arch. oral Biol., v.20, p.713-6, 1975.

70. SMITH, Q. T.; CAMPS, S. J. Salivary amylase in crevicular fluid. J. clin. Periodont., n.20, p.418-24, 1993.

71. SQUIRE, C. A. The permeability of keratinized an nokeratinized oral epithelium to horseradish peroxidase, J. Ultrastruct. Res., v.43, p. $160-77,1973$.

72. STETLER, K. J.; BISSADA, N. F. Significance of the width of keratinized gingiva on the periodontal status of teeth with submarginal restorations. J. Periodontol., v.58, n.10, p.696-700, Oct., 1987.

73. SUPPIPAT, N.; SUPPIPAT, N. Evaluation of an electronic device for gingival fluid quantitation. J. Periodont. Res., v.48, p.388-94, July 1977.

74. TENENBAUM, H. A clinical study comparing the width of attached gingiva and the prevalence of gingival recessions. J. clin. Periodont., v.9, p.86-92, 1982.

75. TERRANOVA, V. P.; GOLDMAN, H. M.; LISTGARTEN, M. A. O aparelho de inserção periodontal: estrutura, função e química. In: GENCO, R. J.; COHEN, D. W.; GOLDMAN, H. M. Periodontia Contemporânea. São Paulo, Ed. Santos, 1996. p.33-54.

76. TREY, E.; BERNIMOULIN, J. Influence of free gingival grafts on the health of the marginal gingiva. J. clin. Periodont., v.7, p.381-93, 1980. 
77. WEINSTEIN, R. et al. Psychological intervention in patients with poor compliance. J. clin. Periodont., v.23, p.283-8, 1996.

78. WENNSTRÖM, J. L. Lack of association between width of attached gingival and development of soft tissie recession: a 5-year longitudinal study. J. clin. Periodont., v.14, p.181-4, 1986.

79. WENNSTRÖM, J. L.; LINDHE, J. Role of attached gingiva for maintanance of periodontal health: healing following excisional and grafting procedures in dogs. J. clin. Periodont., v.10, p.20621, 1983.

80. WENNSTRÖM, J. L.; LINDHE, J.; NYMAN, S. Role of keratinized gingiva for gingival health. J. clin. Periodont., v.8, p.311-28, 1981.

81. WENNSTRÖM, J. L.; LINDHE, J.; NYMAN, S. The role of keratinized gingiva in plaque-associated gingivitis in dogs. J. clin. Periodont., v.9, p.75-85, Jan. 1982.

82. WILSON JR., T. G. Compliance and its role in periodontal therapy. Periodontology 2000, v.12, p.16-23, 1996.

83. WILSON JR., T. G.; HALE, S.; TEMPLE, R. The results of efforts to improve compliance with suportive periodontal treatment in a private practice. J. Periodont. Res., v.64, n.4, p.311-22, Apr. 1993.

84. WILSON JR, T. G. et al. Compliance with maintenance therapy in a private periodontal practice. J. Periodont. Res., v.55, n.8, p.46873, Aug. 1983. 
ABSTRACT 


\section{ABSTRACT}

\section{CHEWING AND KERATINIZED GINGIVA WIDTH INFLUENCE ON THE GINGIVAL CREVICE PHISIOLOGY}

With the intention of assessing the gingival crevice homeostatic behavior in relation to the keratinized gingiva, and more specifically, directing the analysis to the variation of gingival fluid produced by the chewing of fibrous foods (bovine meet), it was chosen 16 patients in good general health and with clinically healthy homologous pre-molars and molars. The patients presented on the experimental side adequate width of keratinized gingiva (Group $A \geq 2 \mathrm{~mm}$ ), and on the control side insufficient width of keratinized gingiva (Group $B<2 \mathrm{~mm}$ ). The clinical indexes used were: plaque index $(\mathrm{PI})$, gingival bleeding index ( $\mathrm{GBI})$, probing depth (PD), keratinized gingiva width (KGW) and amount of gingival fluid (GF). The amount of gingival fluid was collected before and after the chewing of cooked fibrous food (bovine meat) for ten minutes by the use of absorbing filter paper strips - PerioPaper. The collection of gingival fluid according to LÖE; HOLM-PEDERSEN was initially carried out by the placement of the PerioPaper over the tooth and the mucosa for the staining of the paper strips in the alveolar mucosa region (P1A) and the gingival border (P1B). After that the tip of another strip of paper was placed at the entrance of the gingival crevice (P2). Finally, a third strip was placed intracrevicularly (P3) as proposed by BRILL. All the areas were previously dried with a jet of air, and the strips of papers were kept in place for $1 \mathrm{~min}$ in each of the positions in each group, then removed, allowed to dry and immersed in a nihidrine solution at $2 \%$. After drying the stained areas were measured longitudinally with a digital caliper. The data collected was statistically assessed through Student's paired "t" test. The results in this 
study seem to lead to the conclusion that a greater width of keratinized gingiva results in a better homeostatic behavior of the marginal periodontum, since it interferes with the gingival fluid leaking process: chewing influences the amount of fluid leaked marginally as gingival fluid: the greater the keratinized gingiva the greater seems to be the natural defenses of the gingival crevice.

Key words: Keratinized gingival, gingival fluid, chewing. 